\title{
Relocalizing a historical earthquake using recent methods: The 10 November 1935 Earthquake near Montserrat, Lesser Antilles
}

\author{
P. Niemz ${ }^{\mathrm{a}, *}$, D. Amorèse $\mathrm{b}^{\mathrm{b}, \mathrm{c}}$ \\ ${ }^{a}$ Institut für Geowissenschaften, Friedrich-Schiller-Universität Jena, Burgweg 11, 07749 \\ Jena, Germany \\ ${ }^{b}$ Equipe de Sismologie, Observatoire Volcanologique et Sismologique de Guadeloupe, IPGP, \\ Sorbonne Paris Cité, UMR 7154 CNRS, Univ Paris Diderot, Le Houëlmont, 97113 \\ Gourbeyre, La Guadeloupe, France \\ ${ }^{c}$ Université de Caen-Basse-Normandie, 14032 Caen cedex, France
}

\begin{abstract}
This study investigates the hypothesis of Feuillet et al. (2011) that the hypocenter of the seismic event on November 10, 1935 near Montserrat, Lesser Antilles $\left(M_{S} 61 / 4\right)$ (Gutenberg and Richter, 1954) was mislocated by other authors and is actually located in the Montserrat-Havers fault zone. While this proposal was based both on a Ground Motion Prediction Equation and on the assumption that earthquakes in this region are bound to prominent fault systems, our study relies on earthquake localization methods using arrival times of the International Seismological Summary (ISS). Results of our methodology suggest that the hypocenter was really located at $16.90 \mathrm{~N}, 62.53 \mathrm{~W}$. This solution is about 25 $\mathrm{km}$ north-west of the location proposed by Feuillet et al. (2011) within the Redonda fault system, northward of the Montserrat-Havers fault zone. As depth phases that contribute valuable insights to the focal depth are not included in the ISS data set and the reassociation of these phases is difficult, the error in depth is high. Taking into account tectonic constraints and the vertical extend of NonLinLoc's uncertainty area of the preferred solution we assume that the
\end{abstract}

\footnotetext{
* Corresponding author

Email address: peterniemz@yahoo.de (P. Niemz)
}

Preprint submitted to Elsevier

November 24, 2015

(C) 2015. This manuscript version is made available under the Elsevier user license http://www.elsevier.com/open-access/userlicense/1.0/ 
focus is most probably in the lower crust between $20 \mathrm{~km}$ and the Moho. Our approach shows that the information of the ISS can lead to a reliable solution even without an exhaustive search for seismograms and station bulletins. This is encouraging for a better assessment of seismic and tsunami hazard in the Caribbean, Mexico, South and Central America, where many moderate to large earthquakes occurred in the first half of the 20th century. The limitations during this early phase of seismology which complicate such relocations are described in detail in this study.

Keywords: Historical seismology, Earthquake relocalization, ISS, Lesser Antilles, Montserrat

\section{Introduction}

The Lesser Antilles island arc, extending from Grenada in the south to the Island of Anguilla in the north, results from the subduction of the oceanic lithosphere of the North and South American plates beneath the eastern margin of the Caribbean plate (Meschede and Frisch, 1998; Kopp et al., 2011) (Fig. 1). The slow subduction of the old Atlantic lithosphere ( $90 \mathrm{Ma})$ and a slab in state of extension may be the reason for a partial decoupling of the plates involved in this subduction process. This results in aseismic slip components of plates motion and, consequently, a lower seismicity compared to other island arcs (Stein et al., 1983). Because of these characteristics, detailed knowledge about the distribution of historical earthquake foci is crucial for the appropriate assessment of the regional seismic hazard. The island of Montserrat is located in the northern Lesser Antilles, where the North American plate is subducted. Only two instrumentally recorded earthquakes of Magnitude 6 or greater occurred in the Montserrat region: the historical event of 10 November $1935\left(M_{S} 6\right.$ 1/4) (Gutenberg and Richter, 1954) and the more recent event of 16 March 1985 $\left(M_{S} 6.1-6.8\right)$ (International Seismological Centre, 2011b) (Fig. 2). 
In this study, we tested the hypothesis of Feuillet et al. (2011), claiming that the event of 1935 had been mislocated by previous authors and is actually located in the Montserrat-Havers fault zone at $16.79^{\circ} \mathrm{N}, 62.33^{\circ} \mathrm{W}$ in a depth of $15 \mathrm{~km}$. This hypothesis is based on an intensity attenuation relation and also on the assumption that earthquakes in this region are superficial and bound to prominent fault systems (Feuillet et al., 2011).

In the northern part of the Lesser Antilles, there are two major sets of active normal faults. The first one trending arc-perpendicular toward NE-SW direction cuts the fore-arc reef platforms by half graben structures of $100 \mathrm{~km}$ in length and $50 \mathrm{~km}$ in width corresponding to an arc-parallel extension (Wadge, 1986; Feuillet et al., 2010). The second one, directly associated with the active volcanic arc between Martinique and Saba, is represented by faults with strikes in the arc-parallel direction. Arranged in right-stepping en-echelon patterns, these two fault sets accommodate the trench-parallel component of the relative motion of the North American-Caribbean plate couple. The trench-parallel component of motion becomes prominent northwards where the subduction changes into the northern strike-slip faults of the Greater Antilles (Feuillet et al., 2010). Near Montserrat, the arc-parallel faults are observed in the Montserrat-Havers fault zone, the northerly adjacent Redonda fault, and the Bouillante-Montserrat fault system in the south (Feuillet et al., 2010, 2002) (Fig. 2).

In contrast to the approach of Feuillet et al. (2011), our study relies on the modern localization programs NonLinLoc, HYPOCENTER and HYPOSAT (Lomax et al., 2009; Lienert et al., 1986; Ottemöller et al., 2013) to obtain a hypocenter location from the data given in the listing of the International Seismological Summary (ISS) which was made available for researchers by Villaseñor et al. (1997). Our improved, instrumentally-constrained solution is based on an accurate reappraisal of the basic data set and on the utilization of recent global 
spherical velocity models such as iasp91 (Kennett and Engdahl, 1991) or the even more up-to-date model ak135 (Kennett et al., 1995). Owing to a full probabilistic solution, the global direct-search approach of NonLinLoc proved useful for badly-constrained data sets. Offering the most comprehensive locations compared to other location programs, it was used as our principal localization software.

The hypocenter of the 10 November 1935 earthquake, as determined by this study, is located at $16.90^{\circ} \mathrm{N}, 62.53^{\circ} \mathrm{W}$ within the lower crust in the Redonda fault system. This solution is approximately $25 \mathrm{~km}$ northwest of the location proposed by Feuillet et al. (2011). Depth phases, which help gain valuable insights into the focal depth estimate are not included in the ISS data set and the reassociation of these phases proves to be difficult. As a consequence, we can guess that the error in our depth determination is important: nevertheless, it cannot be precluded that the source for the 1935 earthquake is relatively deep in the crust. Our approach demonstrates that the ISS data may lead to a reliable solution even without an exhaustive search for seismograms and station bulletins. A similar approach in regard to the global seismicity is underway at the International Seismological Centre (ISC) which produces and maintains the ISC-GEM Catalog as an authoritative source for global earthquake locations. It is planned to be extend to include also moderate historical events until 2017 (Bondár and Storchak, 2011; Bondár et al., 2015, http://www.isc.ac.uk/iscgem/work.php, 5 November 2015). Though, our study is not exclusively aiming onto an improved location and a more detailed assessment of the extent and the position of the location uncertainty area for the event on 10 November 1935 as a starting point for further regional studies. It also intends to give detailed insights into the limitations of early seismology. 


\section{Methods}

\subsection{Localization software and velocity models}

Generally, there are two different major techniques for the solution of the location problem. The first approach is based on a linearized-iterative method developed by Geiger (1912). The solution of these iterations is a single maximum likelihood estimation of origin time and hypocenter with a centered ellipsoidal error estimation as given by the localization programs HYPOCENTER or HYPOSAT (Lomax et al., 2009). This technique may be good enough for high-quality data but it is not suitable for poorly-constrained events with a small number of recorded phases or a reduced reliability of the used data set (Lee and Baker, 2006), as is the case for this study. The second approach is the probabilistic non-linear localization of earthquakes. It uses a global directsearch or stochastic algorithms to obtain a probability density function (PDF) that includes all possible locations and origin times with a probability value for each parameter. Thus, it provides information about the uncertainty of the hypocenter location due to errors in travel-time calculation, station distribution or the incompatibility of picks and their Gaussian errors within a full probabilistic solution. A major advantage of this solution, as determined by the NonLinLoc software, is the fact that, even for low quality observations where the hypocenter and/or the origin time cannot be completely constrained, it may still indicate an area of uncertainty containing a most probable solution based on the given ak135 velocity model and the assumption of a Gaussian error distribution (Lomax et al., 2009). However, it does not necessarily contain the correct location since the chosen model may deviate from the true local velocity distribution and the error distribution is nonlinear especially for phase picks in early seismological times. In short, NonLinLoc shares the same weakness as other software when the chosen velocity model is wrong but, as a grid-search 
location software, it provides a highly reliable area of uncertainty from a mathematical viewpoint. This later point makes its use helpful anyway. Using the programs HYPOSAT and HYPOCENTER, we compared the two techniques of localization: the direct-search and the linearized-iterative methods. This diversification in the calculation was endorsed due to the low reliability of the original ISS data set. Additionally, we used different velocity models, taking into account the lack of knowledge regarding the most appropriate model for the crustal velocity distribution beneath the Montserrat region.

\subsection{An a priori error estimation in phase picking}

The knowledge regarding the error of the reported phase onsets is crucial to obtain a reliable location including its uncertainties, especially, but not exclusively for probabilistic approaches. As a matter of fact, the error in travel time calculations, introduced by inhomogeneities of the tectonic setting, is small compared to the impact of error pickings (Lomax et al., 2009; Lomax, 2013). The ISS had to rely on station bulletins submitted by institutions around the world. Hence, its basic data set is characterized by a highly heterogeneous quality (Agnew, 2002). The introduction of radio time signals used for calibration in the 1920's made timing more accurate, but it was still far from today's standard. This is noticeable by numerous timing errors identified in the ISS data set. In addition, instruments used in the beginning of the 20th century had a low dynamic range and a narrow frequency band. Therefore, the signal could not be recorded as detailed as with modern broadband seismographs. Furthermore, even similarly constructed seismographs could differ significantly in their settings (e.g. free period, damping, magnification, polarity, recording speed) as they were mostly installed by non-organized institutions or individuals (Agnew, 2002). Although it is always worth striving for deeper knowledge of the recording instruments (Batlló et al., 2008), our research aimed for a result without 
the exhausting search for historical seismograms and detailed information about the recording systems.

The seismographs of Milne-Shaw, Omori and Wiechert, which were commonly used in that time, were sufficient for teleseismic recordings. Notwithstanding, their time resolution was limited to 1-2 sec (Kanamori et al., 2012) or even 3 sec (Lee, 2006). In contrast, electromagnetic seismographs of Galitzin or Benioff could record with a resolution of approximately $1 \mathrm{sec}$ (Lee, 2006), which corresponds to the precision of the onsets reported in the ISS. The typical issue of losing the $\mathrm{S}$ onset in the $\mathrm{P}$ coda is less present for teleseismic observations since phases arrive with larger differences in time. Nevertheless, some phases arriving close to each other might be misassociated. For this reason, the error of each reported phase onset should not only include the picking uncertainty, but also a possible uncertainty of phase association (Lomax et al., 2009). Taking into account the resolution limits of most seismograms in the 1930's and the resulting errors, the overall error is assumed to be $3 \mathrm{sec}$, without regard to the recording instrument. This estimation is made conservatively, as Lomax (2005) used this value also for the relocalization of the great San Francisco earthquake of 1906, in times when instrumental limitations were much more important.

\subsection{Configurations}

\subsubsection{Linearized Approaches: HYPOCENTER and HYPOSAT}

The localization program HYPOCENTER is based on a damped least-square method, which stabilizes the calculation by linking the Root Mean Square (RMS) to a damping factor (Lienert et al., 1986; Ottemöller et al., 2013). The qualitative weighting zero was set to $3 \mathrm{sec}$ corresponding to the error estimation of phase picking. Phase onsets were weighted by the distance of the receiver station, azimuthal errors and a bisquare weighting to normalize residuals (Ottemöller et al., 2013). 
The ISS solution $\left(16.7^{\circ} \mathrm{N}, 62.5^{\circ} \mathrm{W}\right)$ was defined as starting location for HYPOCENTER as well as HYPOSAT. For teleseismic localizations, both programs take advantage of the relative timing between $\mathrm{S}$ and $\mathrm{P}$, the full set of iasp91 phases and the corresponding iasp91 layered spherical velocity model (Schweitzer, 1997; Lienert, 1994; Kennett and Engdahl, 1991). In addition, HYPOSAT uses travel-time differences between all phases arriving at a single station, azimuthal information and further velocity models as the Jeffreys-Bullen tables (JB) (Jeffreys and Bullen, 1940) or the ak135 model (Kennett et al., 1995), the most advanced one for teleseismic localization which is based on the iasp91 tables (Lomax, 2005; Engdahl et al., 1998).

The starting focal depth for our localizations was fixed at $20 \mathrm{~km}$, but it was freed when the location became stable in the iteration process. Before each iteration in the localization process, all equations are weighted by the standard deviations of phase arrival times, azimuths and ray parameters. Thereby, changes are limited for parameters which are already reasonably well-constrained. In case of erroneous data, this procedure improves the localization by reducing the source-depth error as well as the influence of the aberration between the velocity model and the actual structure beneath the station (Schweitzer, 1997).

\subsubsection{Direct Approach: NonLinLoc}

NonLinLoc was configured to search for the hypocenter using the Oct-tree algorithm based on 100,000 samples within the region $16^{\circ} \mathrm{N}-19^{\circ} \mathrm{N}$ and $60^{\circ} \mathrm{W}$

- $64^{\circ} \mathrm{W}$. For the localizations, we applied an EDT likelihood function, which aims at fitting the phases of most stations, but does not strictly include all outliers, unlike the common L2-norm. The LOCGAU2 function, which controls the distance dependent error estimation in the travel time calculations, was set to $1 \%$ but at most 2 sec (Lomax et al., 2000; Lomax, 2013). All global travel time tables were calculated by the TauP Toolkit (Crotwell et al., 1999) on a 2D grid of 
epicentral distances and depths. Steps of $0.1^{\circ}$ between $0^{\circ}$ and $180^{\circ}$ and steps of $2.5 \mathrm{~km}$ between 0 and $700 \mathrm{~km}$ were chosen, as suggested by Lomax (2005) for the relocation of the Great San Francisco earthquake in 1906, a shallow event such as expected for the 1935 event near Montserrat. The following phases including their depth phases were used: Pn, Sn, P, S, PKP, SKS, SKP, PKS, PcP, ScP, PcS, ScS, PP, PS, SP, SS, SSS. Besides using the three global models mentioned before, we integrated the crustal layers of two regional models into the ak135 tables. These regionally adapted models, dorelak135 and ladleak135, were each named after the author or the project responsible for the development of the model. The first one is defined as a three-layer model with interfaces located at depths of $3 \mathrm{~km}, 15 \mathrm{~km}$ and $30 \mathrm{~km}$ and velocity values of $3.5 \mathrm{~km} / \mathrm{s}, 6 \mathrm{~km} / \mathrm{s}$ and $7 \mathrm{~km} / \mathrm{s}$, respectively. The $\mathrm{V}_{p} / \mathrm{V}_{s}$ ratio is 1.85 and the upper mantle velocity is taken to be $8 \mathrm{~km} / \mathrm{s}$ (Dorel, 1981). The second regional model is a two layered gradient model used by the Seismic Research Center of the University of the West Indies for localizations in the Southern Antilles. At its two discontinuities, located at depths of $8 \mathrm{~km}$ and $35 \mathrm{~km}$, the P-velocity increases from $3 \mathrm{~km} / \mathrm{s}$ to 4 $\mathrm{km} / \mathrm{s}$ and from $5 \mathrm{~km} / \mathrm{s}$ to $6.6 \mathrm{~km} / \mathrm{s}$, respectively. For the underlying first upper mantle layer, a P-velocity of $7.9 \mathrm{~km} / \mathrm{s}$ is suggested. The $\mathrm{V}_{p} / \mathrm{V}_{s}$ ratio is 1.732 (LADLE Study Group, 1983, L. Lynch, pers. comm., 5 March 2013). This gradient model was integrated into the stepwise ak135 model by layers of $4 \mathrm{~km}$, reaching down to the Moho.

\subsection{Reassociation of phases and compilation of data sets}

The listing of the ISS provides 196 phase readings for the 10 November 1935 earthquake near Montserrat. Besides the identification and the removal of outliers within the data set, a correct phase association is crucial for a reliable high-quality relocalization (Lomax, 2005). Unfortunately, for additional phases (depth phases and reflected phases) especially, wrong associations are 
more likely to occur, since it is difficult to distinguish particular phases without the knowledge of exact theoretical arrival times, which was limited in the 1930's (Havskov and Ottemöller, 2010). Contaminations by signals of local or regional events at the same time are also possible sources of misassociations. In addition, each station's observer merely having his own records, the correct association of teleseismic phases was difficult in the 1930's (Lehmann, 1970).

In case additional phases were reported relative to a surrogate origin time, we recalculated the onsets from the general origin time of the ISS solution. With the data set consisting of all associated phases reported in the ISS (data set D1), we calculated a preliminary hypocenter location from each velocity model. Subsequently, every phase onset in the input file with a residual larger than 3 sec was declassified, thereby allowing NonLinLoc to perform an automatic reassociation of these phases within the localization process. For the reassociation, phases were only accepted if the residual was smaller than 6 sec after the first iteration of the localization process, and smaller than $3 \mathrm{sec}$ in the following ones. In this step, the algorithm aims at fitting the reported onsets with the prediction of the underlying velocity model by minimizing their residuals. However, this procedure may result, for example, in the misinterpretation of a $\mathrm{P}$ onset that was picked too late as an alleged pP phase. Such an outcome, purely supported by a better fit, requires a manual double-check. The manual review rests on sets of travel time tables for different velocity models and several hypothetical hypocenters of the 1935 event scattered in the region of interest. Furthermore, a theoretical appearance of a phase does not necessarily imply its visibility in the seismogram because amplitudes generally decrease by epicentral distance and are dependent on focal mechanisms and on the geological structure beneath the recording station. Though, at certain distances, phases with well isolated onsets or large amplitudes compared to other phases can be fairly distinct, even 
in older seismograms (Lehmann, 1970).

Even though the rejection of phases is often a loss of information, it can also increase the reliability of the data set by excluding phases with large picking errors or misassociations. Arrivals that could be associated to multiple theoretical phases within the assumed error of $3 \mathrm{sec}$, according to the travel time tables of different velocity models, were rejected to avoid a possible misassociation. Moreover, phases that could not be associated to any theoretical phase within an error of $3 \mathrm{sec}$, even under the assumption of a possible shift in station timing, were also excluded. Such a shift is assumed in case of two distinct phase arrivals with a similar error larger than $3 \mathrm{sec}$. Applying to this case, the onsets of $\mathrm{P}$ and $\mathrm{S}$ from both stations, Huancayo and Ottawa, were used solely with the corresponding relative onset timing. In case the first arriving $\mathrm{P}$ felt victim to the outlier rejection, as for station LPZ, further phases were kept when having residuals smaller than $3 \mathrm{sec}$.

Generally, automatic phase reassociations were only accepted in case the phases predicted by theoretical travel times were coincident with the corresponding assumption of visibility. Some examples are given below. Whereas PP is rarely well recorded for epicentral distances smaller than $30^{\circ}$, it becomes one of the largest phases in the seismogram beyond this distance (Lehmann, 1970). This characteristic allowed us to confirm the association of PP phases reported from Little Rock $\left(34.8^{\circ}\right)$ and Florissant $\left(38.8^{\circ}\right)$. Furthermore, phases reflected at the core are clearer for distances below $40^{\circ}$ than for longer distances (Lehmann, 1970). Based on this fact, the ScS reported from Copenhagen $\left(67.7^{\circ}\right)$ was most probably a SKS which arrives nearly at the same time. At approximately $130^{\circ}$, PKS is the most prominent phase in a seismogram (Lehmann, 1970), thus the PKS phase reported from Kodaikanal is reliable. According to the ISS, the S onsets of the stations in Strasbourg and Paris were labeled with a question mark 
and add up to full minutes while having a large residuals. In fact, both onsets were reported with a lower precision of one minute (Rothé, 1938). Thus, they were rejected, along with the $\mathrm{S}$ onsets from Kew and Sofia showing the same pattern.

For the determination of the focal depth and the origin time, additional arrivals (depth phases) recorded shortly after the first $\mathrm{P}$ onset are of crucial interest. However, the distinction between first arriving $\mathrm{P}$ and depth phases is difficult for shallow events (Kulhánek, 2002). Nevertheless, two depth phases, reported from Berkeley and Granada, could be integrated into the refined data set D2. To further improve the reliability of the data a most reliable data set (D3) was created. For this data set all phases except the temporally well separated teleseismic phases SS, PP, ScS, SKS and PKS as well as the first arriving S and $\mathrm{P}$ were rejected as suggested by Lomax (2005) since these phases have distinct travel time branches in travel time diagrams (Astiz et al., 1996). The listings of the data sets D2 and D3 are given in the appendix. As HYPOSAT does not provide any function to mark phases that are to be used only by relative timing, an additional data set was compiled, including exclusively phases with residuals smaller than $3 \mathrm{sec}$ (D4). The two available depth phases from data set D2 were reincluded into data set D4 to restore sparse information regarding the focal depth. The two most reliable data sets D3 and D4 contain 60 and 59 phases respectively, corresponding to $30 \%$ of the original ISS data set which is to be found in the appendix.

\section{Results}

The error of the location is given by the posterior PDF, which is visualized by a scatter plot showing a defined number of samples. Zones with a higher density of points represent a higher probability for the hypocenter location. The 
maximum likelihood hypocenter, the fixed point for the calculation of residuals, reflects the highest probability based on the PDF for the located event. However, it should not be separated from the underlying PDF, which offers the full probabilistic solution. The common location criteria, namely the RMS value, the number of phases and the gap (largest azimuthal angle without observation) are also included to describe the quality of the hypocenter determination (Husen and Hardebeck, 2010) because it facilitate the comparison with other locations. The preliminary relocalizations returned by NonLinLoc from the unprocessed data set D1 showed only minor differences compared to the event location of the ISS. After the rejection of unreliable phases, the solutions for the revised data sets D2 to D4 are shifted northeastward (Fig. 3). The epicenters of D2 and D3 calculated with NonLinLoc are located close to each other and their scatter plots intersect almost completely, while the solution based on the data set D4 is approximately $5 \mathrm{~km}$ away. The solutions determined by HYPOCENTER are arranged similarly, whereas the shift of D4 is approximately $10 \mathrm{~km}$. This analogous pattern for all velocity models, except the JB model, is consistent with the fact that all these are based, directly or indirectly, on the iasp91 model (Kennett et al., 1995). The solutions calculated with the JB tables show a different triangular pattern.

The solutions provided by HYPOSAT entail a general problem. As the error is recalculated after each phase rejection, error estimations become too small, resulting in undersized ellipses (Schweitzer and Kennett, 2007). Additionally, the solutions based on D1 suffer from a depth origin time trade-off because HYPOSAT included all travel time differences of the inconsistent data set. As a result, the HYPOSAT solutions show significant spatial differences in comparison to the HYPOCENTER and NonLinLoc locations of this particular data set. Otherwise, HYPOSAT provided the same pattern of epicenter as previ- 
ously described for the other two programs. As expected, the use of different velocity models had a noticeable influence on the epicenter location. These location changes for one data set can reach up to $10 \mathrm{~km}$ for the JB model but do not exceed $5 \mathrm{~km}$ between the other models. The NonLinLoc solutions from the revised data sets based on the iasp91 model are east of the corresponding ak135 epicenters, whereas the solutions of the models dorelak135 and ladleak135 are located south of their ak135 equivalents. The JB epicenters are north of the other solutions. In case of HYPOSAT the iasp91 localizations are north of ak135 solutions. The scatter clouds of all iasp91 and JB solutions do not differ significantly from those of the corresponding ak135 solutions, neither in form nor in position. Nevertheless, the clouds of the JB solutions are generally larger.

All calculated focal depth values range between 24 and $34 \mathrm{~km}$, except for localizations with the JB tables, which were biased by a depth origin time trade-off. All revised NonLinLoc solutions have a scatter plot dipping southwest. The dip angle differed between the used velocity models: $40^{\circ}$ with the global models, but only $15^{\circ}$ with the regionally adapted ones. At the Moho all scatter clouds are cut. Below this sharp increase in wave velocity only a few points occurred, except for the solutions based on the dorelak135 model. Most probably caused by the shallower Moho of this model, these clouds show a denser scatter below the boundary compared to other models.

\section{Discussion}

\subsection{Influence of the velocity models}

The scatter of locations obtained with different velocity models reflects the error caused by the discrepancy between the used model and the actual Earth's interior, as well as the error caused by inadequacies within the model itself. The former is often the largest error in earthquake localization, but generally diffi- 
cult to identify (Lienert, 1994). Additionally, the regional aspherical velocity distribution at subduction zones with increased P-velocities in the slab may lead to mislocalizations reaching up to $50 \mathrm{~km}$ for steep dipping slabs, even with the most advanced spherical model. This effect is most important for the relocalization of shallow events but has a smaller influence in a global scale (Engdahl et al., 1982, 1998).

Nonetheless, the common horizontal error for teleseismic locations provided by the International Seismological Center (ISC) and the National Earthquake Information Center (NEIC) is approximately $10 \mathrm{~km}$ (Husen and Hardebeck, 2010). Expecting a similar value for this study is unrealistic, since our solutions are based on a badly-constrained starting data set. Following this argumentation, the change in location of approximately $10 \mathrm{~km}$ due to the use of different velocity models is less important. Furthermore, the zones of highest likelihood overlap for the most part.

The origin time offset of the JB solutions is the result of known baseline errors within the JB tables reaching up to 1.8 sec for P onsets (Engdahl et al., 1998; Kennett and Engdahl, 1991). The error estimation in phase picking of $3 \mathrm{sec}$ also contributes to this origin time shift. Finally, this offset is caused by the overall error in the JB tables, which may be as important as the standard errors of the hypocenter parameters (Van der Hilst and Engdahl, 1992). For the solutions based on the ladleak135 model, more complex travel paths in the thin layered approximation to the LADLE regional gradient model may also caused a shift in origin time.

\subsection{Determining the epicenter}

Regarding the network criteria, there are challenging propositions when a reliable epicenter location is obtained. Bondár et al. (2004) postulate that a solution with a gap smaller than $120^{\circ}$ delivers a reliable epicenter, while Lee 
(2006) sets this critical point at $90^{\circ}$. However, it should be preferred to obtain data from stations in all directions relative to the epicenter. This is a general problem of early seismology when stations were more unevenly distributed. While numerous regions of the northern hemisphere already had a high density of seismic stations, mainly in Europe, the USA and Japan, observations in the southern hemisphere were limited by a sparse distribution of seismic stations (McComb and West, 1931). This uneven pattern is reflected in the distribution of stations that recorded the event of Montserrat (Tab. 1).

Since the initial hypocenter in linearized approaches may alter the calculated location its influence was tested using previously suggested locations and the NonLinLoc location for the D4 data set based on the ak135 model which is qualified as test case due to its low RMS. It was found that different initial hypocenters do not change the calculated locations, which means the global minima should be found. Thus, the linearized results provide reliable results, Though, in regard to the uncertainty, NonLinLoc is much more powerful. All solutions determined by HYPOCENTER and HYPOSAT are located in the same area as those of the reference program NonLinLoc - regardless of the appearing gap. Only one solution did not match the criterion of a maximum gap of $120^{\circ}$. This location was calculated by HYPOCENTER and based on data set D4. The underestimation of the error ellipses in HYPOSAT prevented such a solution from being selected as the preferred epicenter, but the corresponding ellipses could contribute to the definition of a zone of interest, located west of Redonda Island (solid-line ellipse in Fig. 3). This zone intersects largely with the $90 \%$ confidence ellipsoid of the HYPOCENTER D3 solution and the zone of highest sample density of the PDF from most NonLinLoc solutions. It excludes only the HYPOSAT solutions of D1 and D3. Furthermore, it overlaps the error ellipses of all other HYPOCENTER solutions (dashed-line ellipses in Fig. 3). 
When excluding the JB solutions, all solutions within this zone show a RMS smaller than $2 \mathrm{sec}$. The minimum RMS values were obtained from the NonLinLoc solutions based on the ak135 model. Nonetheless, the weakest RMS is not a proof, but only an indication, for a most reliable location because the fitting of phases is easier with a smaller number of phases used in the calculation (Husen and Hardebeck, 2010). Moreover, the number of phases only corresponds to phases used with absolute onset timings. Thus, the RMS values of the D2 and D3 localizations, as those of all other HYPOSAT solutions, are actually based on a larger number of observations because they contain also pairs of phases with relative timing.

The defined zone of interest is near or even within the Redonda fault system, a zone of active tectonics in the last 34ka (Beck et al., 2012). On 16 March 1985 a $M>6$ earthquake occurred farther north of this fault system followed by many aftershocks within the ensuing year (International Seismological Centre, 2011b). Focal mechanisms of these events were suggested consistent with fault planes striking $\mathrm{N} 140^{\circ} \mathrm{E}$ and a left lateral motion on the Montserrat-Havers fault system (Feuillet et al., 2010, 2002) (Fig. 4). This implies a similar motion within the Redonda fault system which strikes $\mathrm{N} 110^{\circ} \mathrm{E}$ and dips in a northeastward direction (Feuillet et al., 2010). Under the assumption that the event in 1935 was bound to the Redonda fault system, the NonLinLoc location based on data set D4 and the 135ak model is our preferred solution. It is located within the Redonda fault system at $16.90 \mathrm{~N}, 62.53 \mathrm{~W}$, approximately $25 \mathrm{~km}$ northwest of the location proposed by Feuillet et al. (2011). The Gaussian expectation hypocenter of this final data set coincides almost completely with the maximum likelihood solution, as predicted for a solution with a single maximum and an ellipsoidal scatter of the PDF (Lomax et al., 2000) (Fig. 4) (Tab. 2). Normalized likelihood values from NonLinLoc's octree search grid based on this 
data set show that the hypocenters suggested by previous authors are highly unlikely. With a normalized likelihood of only 0.000164 the location of Feuillet et al. (2011) nevertheless shows the highest value among the suggested locations. By examining residuals and weightings of the preferred solution (Tab. 1) it is seen that the phase reports from LPZ, SUC, CGH and KOD have important weightings. In order to test the influence of phases reported from stations to the south of the event the outlier rejection procedure and the relocalization using NonLinLoc was repeated without taking into account these phases from the south. It was found that the according test solutions (S2 to S4) are located $20 \mathrm{~km}$ to $40 \mathrm{~km}$ to the north of locations based on the whole starting data set (D2 to D4) since the composition of the data set changed (Figure 5). This means that the location shifts and differences in phase association as well as in the outlier rejection are mutually dependent. The northeastward shift described for the standard data sets is also seen for the test data sets. Thus, the phases reported from the southern stations have a large influence onto the latitude of the event location while the longitude is stable and mostly driven by the outlier rejection as it is seen for both the standard data set and the data set without the southern phases. However, the northerly shifted locations would contradict the given macroseismic constraints. Consequently, it is assumed that the important weightings of the phases from the southern stations do not bias the solutions but prevent a bias from the large number of stations to the north.

By applying the $\mathrm{B}^{3}$ macroseismic intensity prediction of Beauducel et al. (2011) on our preferred location it is tested for consistency with respect to reported intensities compiled by Robson (1964) and Feuillard (1985). The location suggested by Feuillet et al. (2011) is based on this regionally adapted MSK intensity attenuation model. Considering the large error of one intensity level attached to these predictions, as well as the known underestimation of intensities for 
larger epicentral distances (Beauducel et al., 2011) the predicted intensities are compatible with the compiled values for Montserrat (VIII), Antigua (VI), St. Kitts (IV) and Martinique (III) used by Feuillet et al. (2011) (Fig. 6). However, intensity reports are prone to errors because they are based on subjective impressions or biased by personal interpretations of words, such as "severe" or "slight" (Richter, 1958). Besides, there exist inconsistent reports from Saint Kitts regarding the extent of the damages. According to Robson (1964) only dishes were shaken, corresponding to an intensity IV. In contrast, Powell (1938) reported damages at the church of Basseterre, the capital city of Saint Kitts and Nevis, implying at least an intensity VI. As a general approach the $\mathrm{B}^{3}$ model (Beauducel et al., 2011) does not consider a possible anisotropic energy release from the hypocenter, the local geological and seismic site effects which strongly influence the intensity values. This is an unremarkable conclusion but it is important to bear in mind that, when usable, instrumental records should be preferably used for earthquake locations, as they provide a higher reliability than macroseismic information (Richter, 1958).

\subsection{Focal depth}

A crucial part of the data evaluation in this study, namely the reassociation of phases, also proved to be the most difficult one. The reassociation based on calculated travel times is only suitable for some distinct phases. Especially for shallow earthquakes, the identification of first arrivals including $\mathrm{P}, \mathrm{sP}, \mathrm{pP}, \mathrm{pwP}$, and $\mathrm{PcP}$ causes difficulties without the review of corresponding seismograms (Engdahl et al., 1998). With early seismographs having time resolutions on the order of some seconds, the identification of phases arriving in quick succession becomes even more difficult. These phases are critical for the determination of focal depth and origin time, but they are often mixed up, resulting in large residuals. However, to obtain a reliable set of phases for the epicenter determination, 
phases with larger residuals were excluded as outliers. Thus, the reassociation of first arriving phases is a balancing act between preserving depth information and compiling a reliable data set. The loss of depth information is reflected in the steeper dip of the scatter clouds for D3 (no depth phase), compared to the clouds for D2 (two depth phases). We further tested the given preferred dataset by calculating fixed depth solutions. As can be seen in Figure 5 the chosen fixed depth may also biases the epicenter location. Deeper event locations tend to be farther south for the dataset without southern stations. For the standard dataset D4 a simulated fixation of the depth using NonLinLoc shows that the spatial difference between the given epicenters is small in regard to the given uncertainty of the D4 solution. The decrease in depth is mostly accommodated by a shift in the event's origin time which varies by as much as $3 \mathrm{sec}$ and results in larger residuals. Furthermore, the included depth phases are registered at teleseismic distances, which may result in an overestimation of the focal depth (Van der Hilst and Engdahl, 1992). Consequently, without waveform studies, this teleseismic approach, extended by the use of some regional stations and a local one, can only deliver a qualitative estimation of the focal depth. Taking into account a suggested Moho depth of 28 to $30 \mathrm{~km}$ for the island arc near Montserrat (Kopp et al., 2011; Sevilla et al., 2010; Bouysse et al., 1990) and the vertical extend of NonLinLoc's uncertainty area the hypocenter of 10 November 1935 event was most probably located in the lower crust. This assumption is also based on depth determinations between 15 and $35 \mathrm{~km}$ for the larger aftershocks of the 16 March 1985 event within the following month (International Seismological Centre, 2011b) (Fig. 7). These hypocenter solutions are better constrained due to the availability of data from more reliable networks and closer stations with modern instrumentation. 


\section{Conclusion}

Based on macroseismic and tectonic constraints, the proposition of Feuillet et al. (2011) to relocate the 1935 event at the prominent main fault of the Montserrat-Havers fault zone tended in the right direction. However, we suggest a significantly corrected hypocenter location for this $\mathrm{M}>6$ earthquake, situated within the Redonda fault system, $25 \mathrm{~km}$ northwest of the solution from Feuillet et al. (2011). Our preferred location was selected among a large number of locations determined with diverse data sets, various velocity models, and three different location algorithms. It was calculated by NonLinLoc based on the data set D4 and the ak135 model. Selection criteria were its vicinity to a prominent fault system, its minimal RMS value and its scatter plot including a large number of other maximum likelihood hypocenters as well as its presence in many other error ellipses. The according linearized localization of HYPOSAT and HYPOCENTER are close to this location but the given location uncertainties are expected to be less reliable compared to the direct-search location uncertainties. As NonLinLoc offers a full probabilistic approach to the problem of earthquake localization, the solution is not only given by a single point but also a PDF, which includes all a priori and posterior information obtained before or during the localization. The maximum likelihood hypocenter, which is additionally indicated by NonLinLoc, corresponds to the common hypocenter presentation in a single point. For our preferred location it is situated at $16.90^{\circ} \mathrm{N}, 62.53^{\circ} \mathrm{W}$ in a depth of $28 \mathrm{~km}$. This result from a direct-search approach confirms the reliability of the ISC-GEM solution since the ISC-GEM epicenter at $16.842 \pm$ $0.055^{\circ} \mathrm{N}, 62.529 \pm 0.056^{\circ} \mathrm{W}$ (Bondár et al., 2015, pers. comm.; ISC,October 2015 ) is included in the scatter plot produced by NonLinLoc. Vice versa, the epicenter suggested in this study is also within the errors bounds of the ISC location. 
For the relocalization, we also used regional and teleseismic S phases, as well as some teleseismic depth phases (pP). Undoubtedly, this kind of approach improves the reliability of the depth determination (Engdahl et al., 1998; Thurber and Engdahl, 2000). Nevertheless, none of the recording stations was located less than one depth distance away from the inferred epicenter, which results in a large uncertainty of the depth (Chatelain et al., 1980). Considering the poor resolution of the depth, we assume that the hypocenter was situated in the lower crust, most probably between a depth of $20 \mathrm{~km}$ and the Moho (28 to $30 \mathrm{~km})$. Our approach shows that a large regional event that was recorded globally in early times of seismology, but with a doubtful reliability, can be successfully relocalized with recent localization methods. Such relocalizations of historical events provide valuable information even for modern seismology concerning long-term earthquake cycles and seismic hazard related to active tectonics because every damaging or lethal earthquake is unique. Of course, this is not the first time that an instrumental historical earthquake or a group of instrumental historical earthquake is relocated with modern means (see for instance, Petroy and Wiens (1989); Doser and Brown (2001); Engdahl and Villaseñor (2002); Engdahl et al. (2007); Bondár et al. (2015)). However, this refined location of a strong shallow earthquake is important for a region where the seismicity is poorly constrained and probabilistic seismic hazard assessment studies (Bozzoni et al., 2011) are currently under way. 


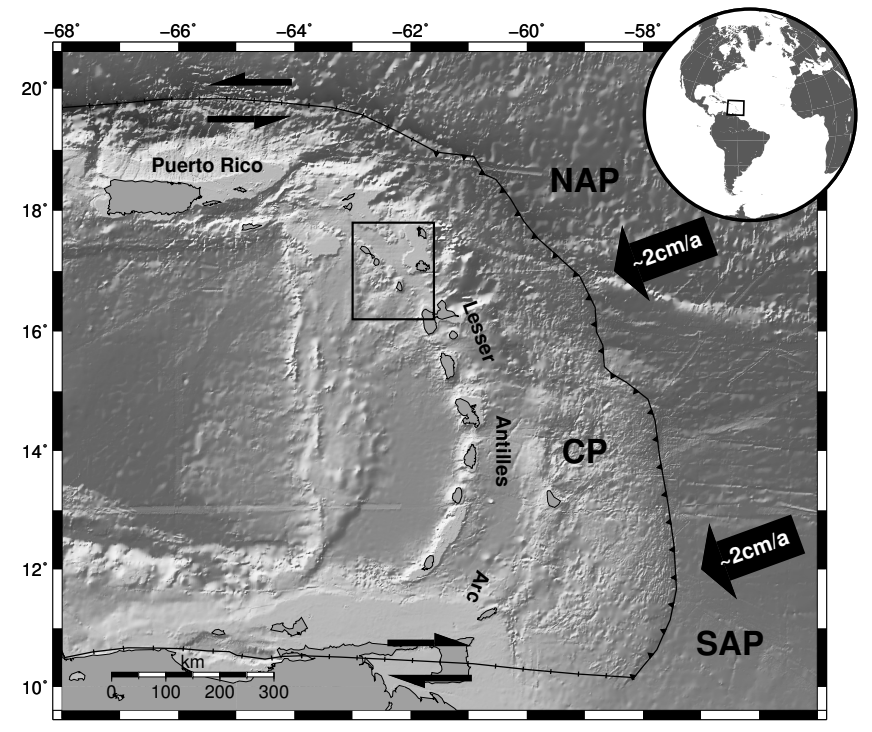

Figure 1: Simplified geodynamic map of the Eastern Caribbean based on plate boundaries from Bird (2003) and the SRTM30 PLUS data set (Becker et al., 2009). Both the North American plate (NAP) and the South American plate (SAP) are subducted under the Caribbean plate (CP) with a velocity of approximately $2 \mathrm{~cm} / \mathrm{a}$ (Weber et al., 2001; DeMets et al., 2000). The Montserrat region (large rectangle) is shown more detailed in Fig. 2. 


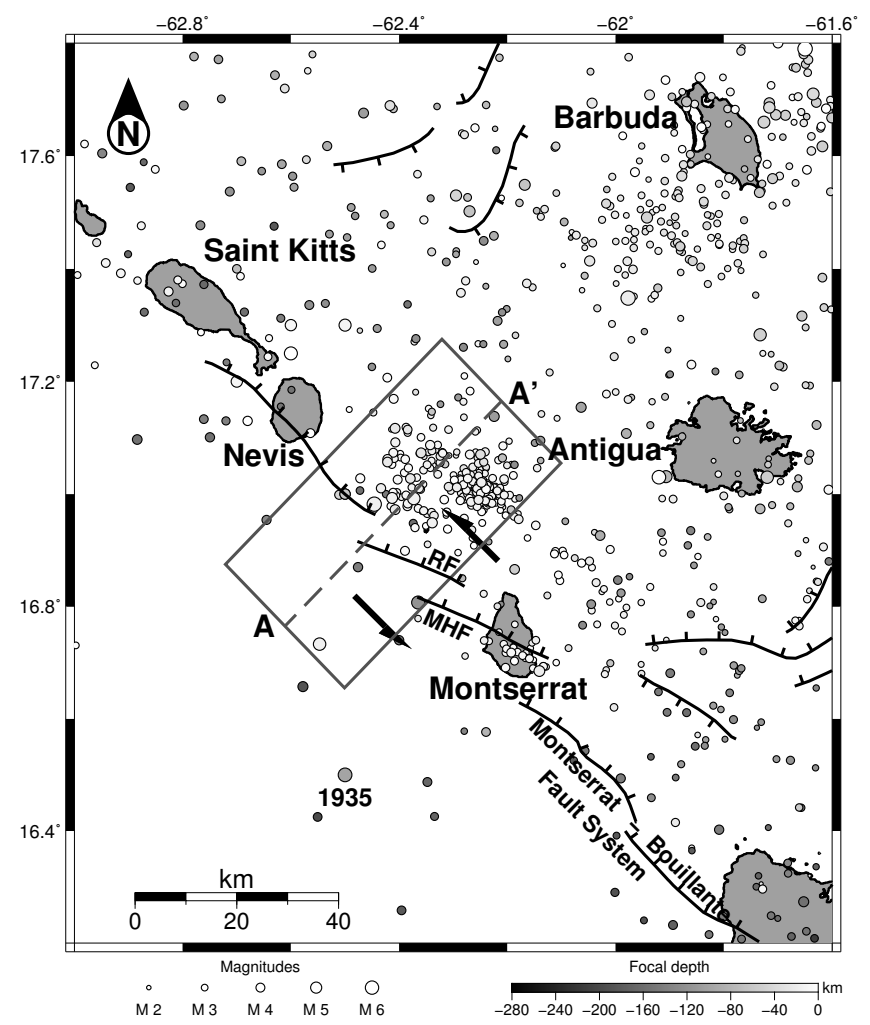

Figure 2: Map of the Northern Lesser Antilles centered on the Montserrat-Havers fault system $(\mathrm{MHF})$ and the Redonda fault $(\mathrm{RF})$. Regional faulting and tectonics were obtained from Feuillet et al. (2010). Hypocenters and magnitudes were extracted from the reviewed ISC catalog (International Seismological Centre, 2011b) starting from 1920. Post-1963 events were filtered by RMS ( $<3 \mathrm{sec})$, magnitude $(<\mathrm{M} 4.6)$, and the number of phases used for localization $(>7)$. Events exceeding M4.6 were extracted from the EHB catalog (International Seismological Centre, 2011a) and filtered by the same criteria. Finally, 850 events with magnitude value from various scales were plotted. The compatibility of these scales is assumed to be mostly achieved since $99 \%$ of the magnitude values for this map are below M5.5. In the ISC catalog the 1935 event is represented by the solution of Gutenberg and Richter (1954). The section A-A', containing a large number of aftershocks of the event on 16 March 1985, is shown in Fig. 7 . 


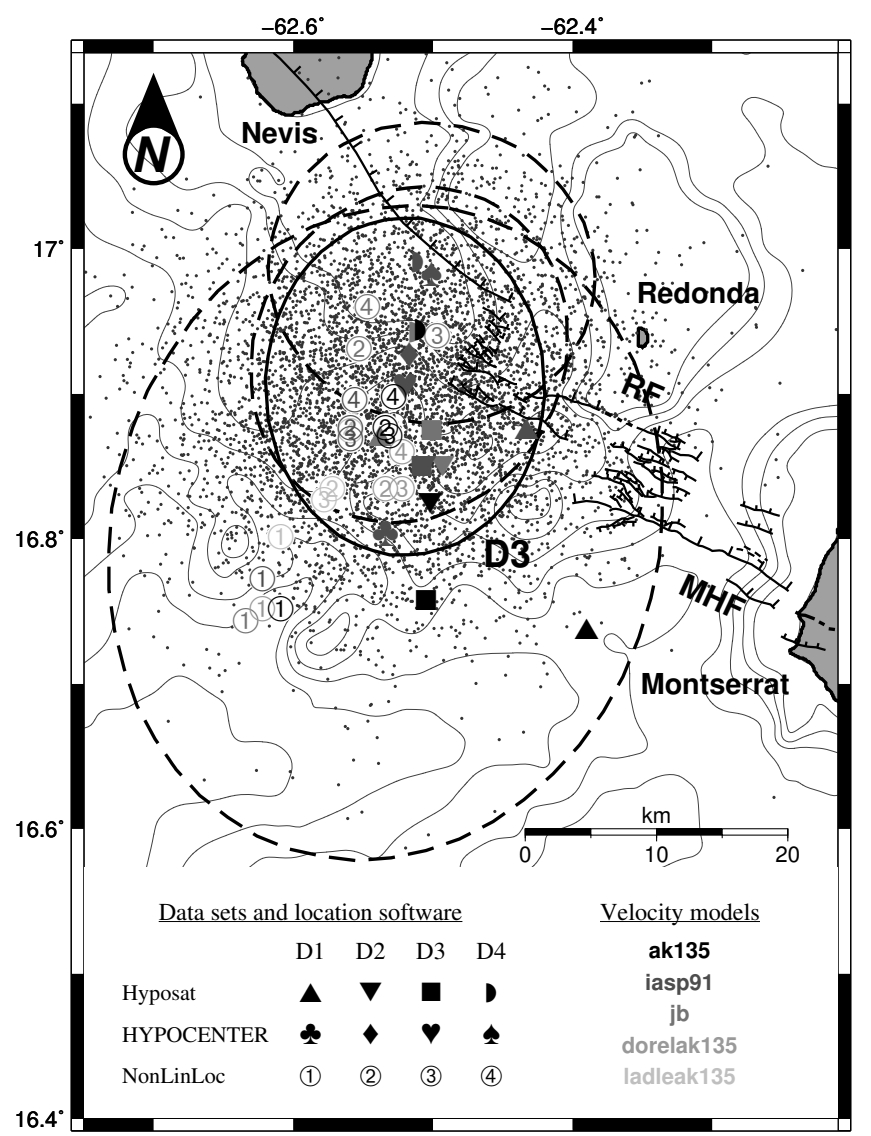

Figure 3: Bathymetric map of the Montserrat-Havers fault system (MHF) and the Redonda fault systems (RF) based on the SRTM30 PLUS data set (Becker et al., 2009). Local faulting and tectonics were obtained from Feuillet et al. (2011) and Feuillet et al. (2010). The 90\% error ellipses of the HYPOCENTER solutions for D1, D2, and D4 are plotted as dashed-line circles. Except for the locations based on data set D1, all determined epicenters are located within a small area. This defined zone of interest is enclosed by the $90 \%$ error ellipse of the HYPOCENTER solution of data set D3 (solid-line). The scatter plot of the NonLinLoc solution based on data set D4 and the ak135 model shows a more detailed error estimation of this hypocenter determination. 


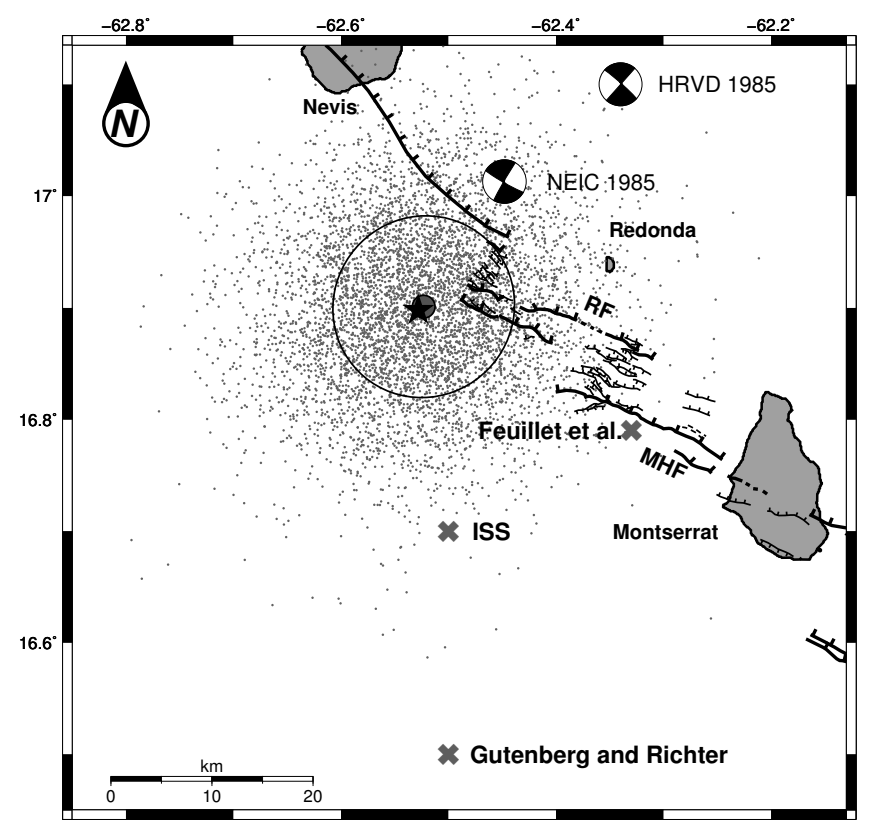

Figure 4: The preferred solution of the 1935 event is shown by the maximum likelihood epicenter (star), with the corresponding scatter plot and the $90 \%$ error ellipse as well as the Gaussian expectation (filled circle). It differs significantly from previously determined locations of the 1935 event from the ISS, Feuillet et al. (2011) and Gutenberg and Richter (1954). The focal mechanisms of the event on 16 March 1985 determined by the NEIC and according to the Harvard Global CMT Catalog (HRVD) were obtained from the International Seismological Centre (2011b). 


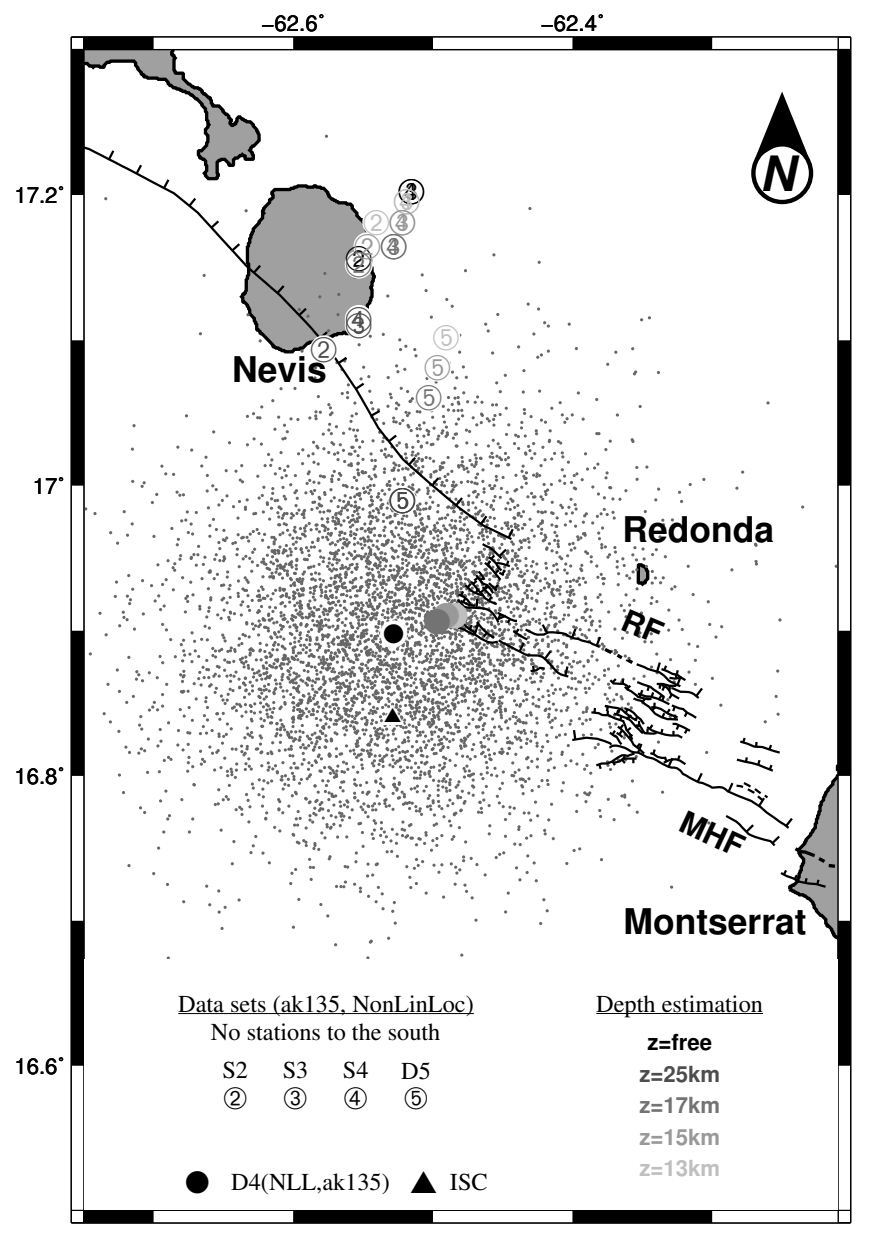

Figure 5: The relocalization based on the reduced starting data set without stations to the south of the event including an independent outlier rejection (S2 to S4) are scattered near the island of Nevis to the north of the preferred solution of this study and the ISC epicenter. Data set D5 corresponds to standard data set D4 without any station to the south of the event. This illustrates the important influence of the phase reports from southern stations onto the event location. When using fixed depths it is obvious that the datasets containing no southern stations are farther south for locations with deeper depth estimates while for the preferred data set D4 this trend is westward. 


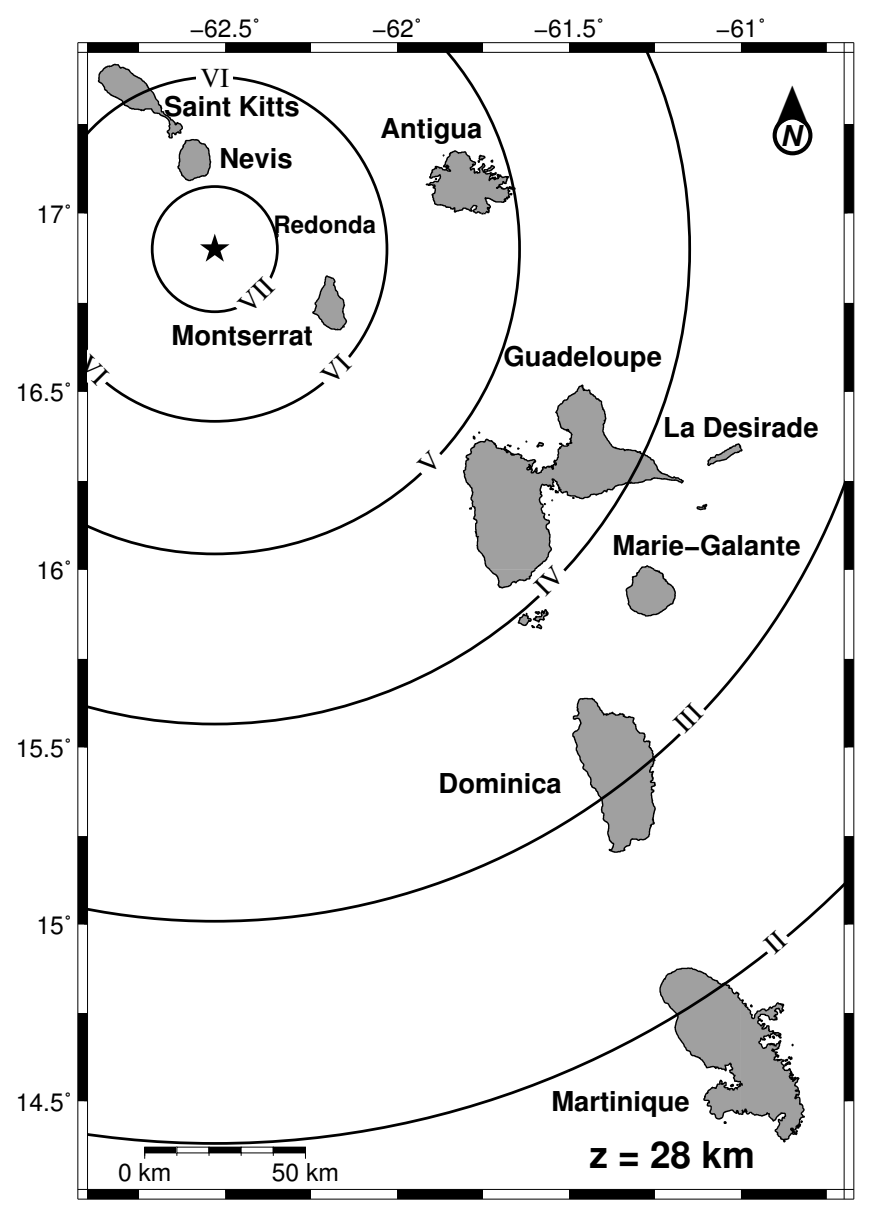

Figure 6: $\mathrm{B}^{3}$ intensity prediction (Beauducel et al., 2011) for the preferred event location (star) at a depth of $28 \mathrm{~km}$. Considering an error of more than one intensity level within the predictions, the calculated intensity distribution is consistent with the reported intensities. 


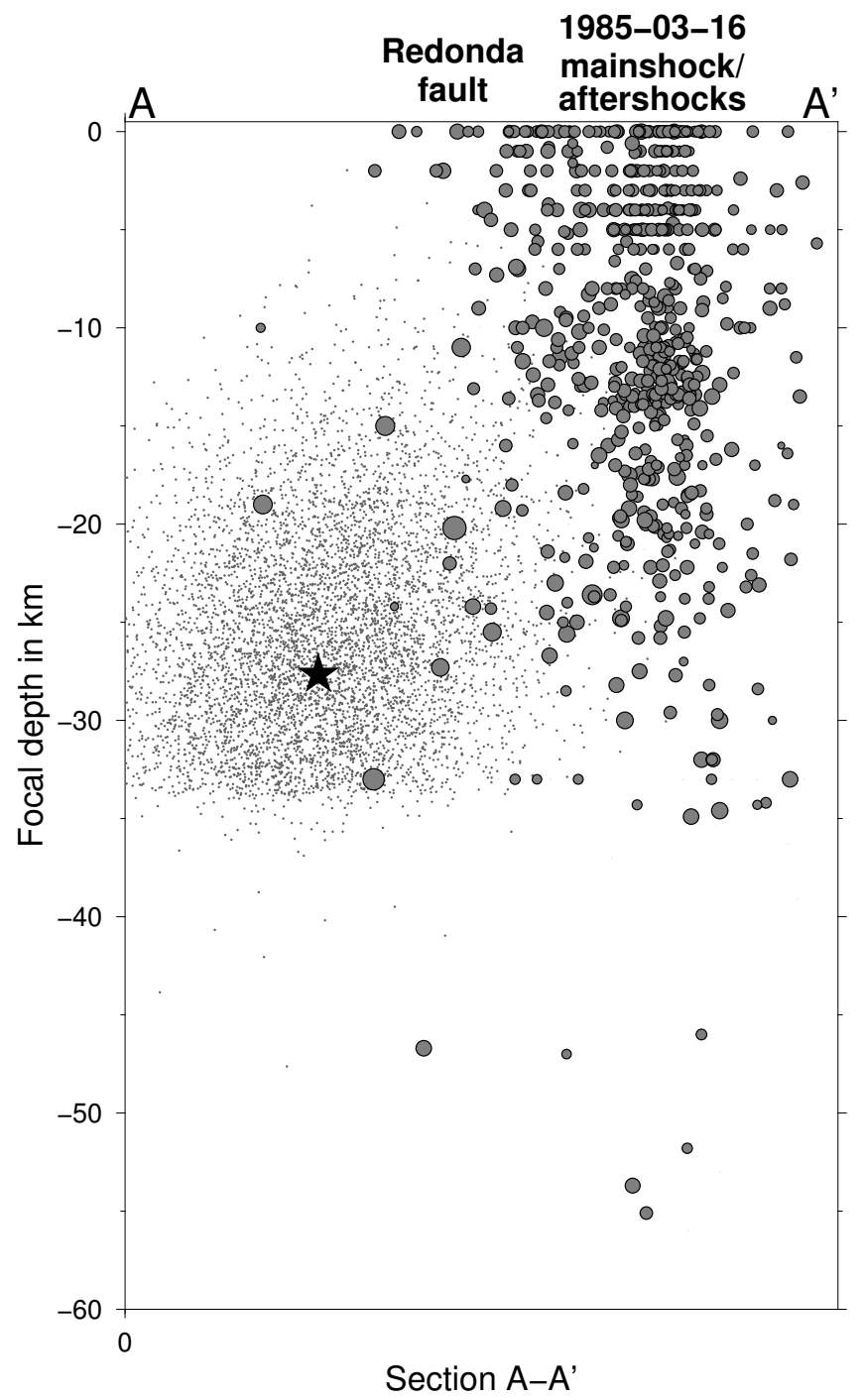

Figure 7: Projection of all hypocenters of the reviewed ISC catalog (International Seismological Centre, 2011b) within the rectangle, defined in Fig. 2, onto section A-A'. The majority of these events were aftershocks of the 16 March 1985 event. The preferred solution (star) is plotted with the corresponding scatter plot given by NonLinLoc. 
Table 1: List of 59 arrival times used in the final data set D4 and their corresponding residuals for the preferred NLL location. The station coordinates were compiled from McComb and West (1931), Wood (1921), Poppe (1979), Schweitzer and Lee (2003) and the ISC station database

\begin{tabular}{|c|c|c|c|c|c|c|c|c|c|c|}
\hline \multirow[b]{2}{*}{ Station } & \multirow[b]{2}{*}{ Code } & \multirow[b]{2}{*}{ Arrival time } & \multirow[b]{2}{*}{ Phase } & \multirow[b]{2}{*}{ Residual (s) } & \multirow[b]{2}{*}{ Weight } & \multirow[b]{2}{*}{ Distance $\left(^{\circ}\right)$} & \multirow[b]{2}{*}{ Azimuth $\left(^{\circ}\right)$} & \multicolumn{3}{|c|}{ Coordinates } \\
\hline & & & & & & & & Lat. & Lon. & Elev. (m) \\
\hline \multirow[t]{2}{*}{$\begin{array}{l}\text { San Juan } \\
\end{array}$} & $\begin{array}{l}\text { SJP } \\
\end{array}$ & $18 \mathrm{~h} 28 \min 40 \mathrm{~s}$ & $\overline{P n}$ & $\begin{array}{c}-0.70 \\
\end{array}$ & 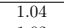 & $\begin{array}{l}3.73 \\
\end{array}$ & $\begin{array}{l}293.98 \\
\end{array}$ & $\begin{array}{ll}18.3817 \\
\end{array}$ & 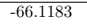 & 8 \\
\hline & & $18 \mathrm{~h} 29 \mathrm{~min} 35 \mathrm{~s}$ & SS & -0.12 & 1.03 & & & & & \\
\hline Balboa Heights & BHP & $18 \mathrm{~h} 32 \mathrm{~min} 00 \mathrm{~s}$ & $\mathrm{P}$ & 2.28 & 0.94 & 18.40 & 246.55 & 8.9608 & -79.5581 & 36 \\
\hline Columbia & $\mathrm{CSC}$ & $18 \mathrm{~h} 32 \mathrm{~min} 54 \mathrm{~s}$ & $\mathrm{P}$ & -1.81 & 0.85 & 23.85 & 319.36 & 34 & -81.0333 & 94 \\
\hline \multirow[t]{2}{*}{ Charlottesville } & CLT & $18 \mathrm{~h} 33 \mathrm{~min} 08 \mathrm{~s}$ & $\mathrm{P}$ & -1.84 & 0.84 & 25.39 & 329.58 & 38.0333 & -78.5167 & 150 \\
\hline & & $18 \mathrm{~h} 37 \min 36 \mathrm{~s}$ & $\mathrm{~S}$ & 1.33 & 0.87 & & & & & \\
\hline \multirow[t]{2}{*}{ Philadelphia } & PHI & $18 \mathrm{~h} 33 \min 12 \mathrm{~s}$ & $\mathrm{P}$ & 0.61 & 0.89 & 25.56 & 337.09 & 39.9589 & -75.175 & 5 \\
\hline & & $18 \mathrm{~h} 37 \mathrm{~min} 35 \mathrm{~s}$ & $\mathrm{~s}$ & -2.40 & 0.80 & & & & & \\
\hline Oak Ridge & HRV & $18 \mathrm{~h} 33 \mathrm{~min} 24 \mathrm{~s}$ & $\mathrm{P}$ & 1.70 & 0.86 & 26.76 & 345.1 & 42.5064 & -71.5583 & 180 \\
\hline Pennsylvania & SCP & $18 \mathrm{~h} 33 \mathrm{~min} 30 \mathrm{~s}$ & $\mathrm{P}$ & 2.54 & 0.80 & 27.34 & 334.13 & 40.795 & -77.865 & 352 \\
\hline Vermont & BUR & $18 \mathrm{~h} 33 \mathrm{~min} 40 \mathrm{~s}$ & $\mathrm{P}$ & -2.56 & 0.79 & 29.03 & 344.19 & 44.48 & -73.1967 & 100 \\
\hline \multirow[t]{2}{*}{ Little Rock } & LRA & $18 \mathrm{~h} 35 \mathrm{~min} 17 \mathrm{~s}$ & PP & 1.69 & 0.86 & 32.07 & 309.66 & 34.7783 & -92.3517 & 150 \\
\hline & & $18 \mathrm{~h} 39 \mathrm{~min} 21 \mathrm{~s}$ & $\mathrm{~s}$ & 1.24 & 0.88 & & & & & \\
\hline Saint Louis & SLM & $18 \mathrm{~h} 34 \mathrm{~min} 13 \mathrm{~s}$ & $\mathrm{P}$ & -0.57 & 0.89 & 32.55 & 317.5 & 38.6361 & -90.2361 & 161 \\
\hline & & $18 \mathrm{~h} 39 \mathrm{~min} 28 \mathrm{~s}$ & $\mathrm{~S}$ & 0.82 & 0.89 & & & & & \\
\hline Florissant & FLO & $18 \mathrm{~h} 34 \mathrm{~min} 14 \mathrm{~s}$ & $\mathrm{P}$ & -1.15 & 0.87 & 32.73 & 317.65 & 38.8017 & -90.37 & 160 \\
\hline & & $18 \mathrm{~h} 35 \mathrm{~min} 23 \mathrm{~s}$ & PP & -0.69 & 0.89 & & & & & \\
\hline & & $18 \mathrm{~h} 39 \mathrm{~min} 29 \mathrm{~s}$ & $\mathrm{~S}$ & -0.98 & 0.88 & & & & & \\
\hline La Paz & LPZ & $18 \mathrm{~h} 39 \mathrm{~min} 49 \mathrm{~s}$ & s & 1.25 & 1.37 & 33.87 & 189.68 & -16.4953 & -68.1327 & 3658 \\
\hline & & $18 \mathrm{~h} 41 \mathrm{~min} 54 \mathrm{~s}$ & SS & -0.37 & 1.40 & & & & & \\
\hline Madison & MDS & $18 \mathrm{~h} 40 \mathrm{~min} 00 \mathrm{~s}$ & S & -1.30 & 0.86 & 34.75 & 324.56 & 43.0765 & -89.4089 & 270 \\
\hline Sucre & SUC & $18 \mathrm{~h} 34 \mathrm{~min} 42 \mathrm{~s}$ & $\mathrm{P}$ & -2.10 & 1.35 & 36.07 & 184.4 & $\begin{array}{l}-19.0467 \\
-\end{array}$ & -65.2644 & 2850 \\
\hline Tucson & TUO & $18 \mathrm{~h} 36 \mathrm{~min} 04 \mathrm{~s}$ & $\mathrm{P}$ & -2.87 & 0.80 & 46.14 & 298.79 & 32.2467 & -110.835 & 770 \\
\hline Bozeman & BZM & $18 \mathrm{~h} 43 \min 39 \mathrm{~s}$ & $\mathrm{~S}$ & 1.21 & 0.90 & 49.43 & 316.4 & 45.6669 & -111.0453 & 1490 \\
\hline La Jolla & LJC & $18 \mathrm{~h} 36 \mathrm{~min} 49 \mathrm{~s}$ & $\mathrm{P}$ & 0.33 & 0.95 & 51.59 & 298.88 & 32.8633 & -117.2533 & 8 \\
\hline Riverside & RVR & $18 \mathrm{~h} 36 \mathrm{~min} 49 \mathrm{~s}$ & $\mathrm{P}$ & -1.09 & 0.93 & 51.78 & 300.3 & 33.9933 & -117.375 & 260 \\
\hline Mt Hamilton & MWC & $18 \mathrm{~h} 36 \mathrm{~min} 56 \mathrm{~s}$ & P & 1.58 & 0.92 & 52.36 & 300.54 & 34.2238 & -118.058 & 1730 \\
\hline Pasadena & PAS & $18 \mathrm{~h} 36 \mathrm{~min} 55 \mathrm{~s}$ & $\mathrm{P}$ & -0.07 & 0.95 & 52.45 & 300.43 & 34.1484 & -118.1711 & 257 \\
\hline Haiwee & HAI & $18 \mathrm{~h} 36 \mathrm{~min} 56 \mathrm{~s}$ & $\mathrm{P}$ & 0.90 & 0.94 & 52.45 & 302.95 & 36.1367 & -117.947 & 1150 \\
\hline Tinemaha & TIN & $18 \mathrm{~h} 36 \mathrm{~min} 57 \mathrm{~s}$ & $\mathrm{P}$ & -0.52 & 0.94 & 52.78 & 304.07 & 37.055 & -118.228 & 1195 \\
\hline San Fernando & SFS & $18 \mathrm{~h} 44 \mathrm{~min} 28 \mathrm{~s}$ & $\mathrm{~S}$ & -1.92 & 0.93 & 53.21 & 56.73 & 36.4656 & -6.2055 & 21 \\
\hline Santa Barbara & $\mathrm{SBC}$ & $18 \mathrm{~h} 37 \min 05 \mathrm{~s}$ & $\mathrm{P}$ & 0.40 & 0.96 & 53.74 & 300.68 & 34.4408 & -119.7149 & 61 \\
\hline Granada & CRT & $18 \mathrm{~h} 37 \mathrm{~min} 14 \mathrm{~s}$ & $\mathrm{P}$ & -2.32 & 0.90 & 55.36 & 56.08 & 37.19 & -3.5956 & 774 \\
\hline & & $18 \mathrm{~h} 37 \min 26 \mathrm{~s}$ & $\mathrm{pP}$ & 1.15 & 0.98 & & & & & \\
\hline Berkeley & BRK & $18 \mathrm{~h} 37 \mathrm{~min} 22 \mathrm{~s}$ & $\mathrm{P}$ & 0.73 & 0.95 & 56.05 & 304.68 & 37.8735 & -122.261 & 49 \\
\hline & & $18 \mathrm{~h} 37 \min 28 \mathrm{~s}$ & $\mathrm{pP}$ & -1.81 & 0.90 & & & & & \\
\hline Victoria & VIC & $18 \mathrm{~h} 45 \min 40 \mathrm{~s}$ & $\mathrm{~S}$ & 2.26 & 0.88 & 58.30 & 317.12 & 48.5194 & -123.415 & 197 \\
\hline Edinburgh & EDI & $18 \mathrm{~h} 45 \mathrm{~min} 48 \mathrm{~s}$ & $\mathrm{~S}$ & -0.20 & 0.95 & 59.11 & 34.19 & 55.9233 & -3.1861 & 125 \\
\hline Uccle & UCC & $18 \mathrm{~h} 38 \mathrm{~min} 08 \mathrm{~s}$ & $\mathrm{P}$ & 2.19 & 0.90 & 62.49 & 40.97 & 50.7983 & 4.3594 & 10 \\
\hline & & $18 \mathrm{~h} 46 \mathrm{~min} 30 \mathrm{~s}$ & $\mathrm{~S}$ & -1.39 & 0.93 & & & & & \\
\hline DeBilt & DBN & $18 \mathrm{~h} 46 \mathrm{~min} 42 \mathrm{~s}$ & S & 2.29 & 0.89 & 63.15 & 39.59 & 52.1017 & 5.1767 & 3 \\
\hline Strasbourg & STR & $18 \mathrm{~h} 38 \mathrm{~min} 21 \mathrm{~s}$ & $\mathrm{P}$ & 1.95 & 0.92 & 64.49 & 43.66 & 48.5845 & 7.7658 & 135 \\
\hline Stuttgart & STU & $18 \mathrm{~h} 38 \mathrm{~min} 27 \mathrm{~s}$ & $\mathrm{P}$ & 1.76 & 0.93 & 65.44 & 43.5 & 48.7719 & 9.195 & 360 \\
\hline Copenhagen & $\mathrm{COP}$ & $18 \mathrm{~h} 38 \mathrm{~min} 41 \mathrm{~s}$ & $\mathrm{P}$ & 1.26 & 0.95 & 67.71 & 36.06 & 55.6853 & $\begin{array}{r}12.4325 \\
\end{array}$ & 13 \\
\hline & & $18 \mathrm{~h} 47 \min 38 \mathrm{~s}$ & $\mathrm{~s}$ & 2.47 & 0.88 & & & & & \\
\hline & & $18 \mathrm{~h} 48 \mathrm{~min} 34 \mathrm{~s}$ & SKS & -1.88 & 0.91 & & & & & \\
\hline Triest & TRS & $18 \mathrm{~h} 38 \mathrm{~min} 43 \mathrm{~s}$ & $\mathrm{P}$ & -2.00 & 0.92 & 68.55 & 46.88 & 45.6428 & 13.7539 & 8 \\
\hline & & $18 \mathrm{~h} 47 \min 46 \mathrm{~s}$ & $\mathrm{~S}$ & 0.46 & 1.00 & & & & & \\
\hline Prague & PRA & $18 \mathrm{~h} 47 \min 48 \mathrm{~s}$ & $\mathrm{~S}$ & -1.21 & 0.96 & 68.86 & 42.12 & 50.0703 & 14.4331 & 225 \\
\hline Pulkovo & PUL & $18 \mathrm{~h} 39 \mathrm{~min} 35 \mathrm{~s}$ & $\mathrm{P}$ & 0.29 & 1.01 & 76.92 & 31.09 & 59.7667 & 30.3167 & 65 \\
\hline & & $18 \mathrm{~h} 49 \mathrm{~min} 20 \mathrm{~s}$ & $\mathrm{~S}$ & -0.93 & 0.99 & & & & & \\
\hline Moscow & MOS & $18 \mathrm{~h} 40 \mathrm{~min} 01 \mathrm{~s}$ & $\mathrm{P}$ & 0.20 & 1.04 & 81.71 & 34.06 & 55.7383 & 37.625 & 121 \\
\hline & & $18 \mathrm{~h} 55 \mathrm{~min} 29 \mathrm{~s}$ & SS & -0.47 & 1.03 & & & & & \\
\hline Simferopol & SIM & $18 \mathrm{~h} 40 \min 09 \mathrm{~s}$ & $\mathrm{P}$ & 2.66 & 0.93 & 82.77 & 45.13 & 44.949 & 34.116 & 275 \\
\hline Helwan & HLW & $18 \mathrm{~h} 50 \mathrm{~min} 42 \mathrm{~s}$ & SKS & 1.77 & 1.07 & 84.97 & 60.31 & 29.8583 & 31.3417 & 116 \\
\hline Ksara & KSA & $18 \mathrm{~h} 40 \mathrm{~min} 31 \mathrm{~s}$ & $\mathrm{P}$ & 1.13 & 1.09 & 87.46 & 55.35 & 33.8233 & 35.89 & 920 \\
\hline Cape Town & CGH & $18 \mathrm{~h} 51 \mathrm{~min} 23 \mathrm{~s}$ & SKS & $\begin{aligned} & 1.10 \\
-0.69 & \end{aligned}$ & 2.84 & $\begin{array}{l}92.26 \\
92.26\end{array}$ & $\begin{array}{l}124.91 \\
1240\end{array}$ & $\begin{array}{l}5.0250 \\
-33.9333\end{array}$ & $\begin{array}{r}50.09 \\
18.4833\end{array}$ & 13 \\
\hline Tashkent & TAS & $18 \mathrm{~h} 52 \mathrm{~min} 35 \mathrm{~s}$ & $\mathrm{~S}$ & -0.75 & 1.26 & 106.77 & 35.75 & 41.325 & 69.295 & 470 \\
\hline Kodaikanal & KOD & $18 \mathrm{~h} 50 \mathrm{~min} 25 \mathrm{~s}$ & PKS & 1.40 & 1.88 & 13214 & 121.59 & 10.2333 & 77.4667 & 2345 \\
\hline
\end{tabular}


Table 2: Preferred location of the 10 November 1935 event, corresponding error estimation and network criteria

Origin time

$18 \mathrm{~h} 27 \mathrm{~min} 45 \mathrm{sec}$

\begin{tabular}{cccccc}
\multicolumn{2}{c}{ Maximum likelihood hypocenter } & \multicolumn{3}{c}{ Expectation hypocenter } \\
\hline \hline Lat. & Lon. & Depth & Lat. & Lon. & Depth \\
$16.90^{\circ}$ & $-62.53^{\circ}$ & $28 \mathrm{~km}$ & $16.90^{\circ}$ & $-62.52^{\circ}$ & $25 \mathrm{~km}$ \\
& & & & & \\
RMS & No. $\mathrm{Ph}$ & Gap & Min. & station dist. \\
\hline $1.37 \mathrm{sec}$ & 59 & $61.28^{\circ}$ & \multicolumn{2}{c}{$3.73^{\circ}$}
\end{tabular}

$68 \%$ Error ellipsoid centered in the expectation hypocenter

\begin{tabular}{ccccccc}
\hline EllAz1 & Dip1 & Len1 & Az2 & Dip2 & Len2 & Len3 \\
$81.0^{\circ}$ & $75.3^{\circ}$ & $9.9 \mathrm{~km}$ & $314.3^{\circ}$ & $8.9^{\circ}$ & $15.1 \mathrm{~km}$ & $16.7 \mathrm{~km}$
\end{tabular}




\section{Acknowledgement}

This is IPGP contribution ****. P. N. would like to thank the IPGP and its "Direction des Observatoires" (P. Agrinier) for the research grants that have partially funded his 5-month stay at the Guadeloupe Earthquake and Volcano Observatory. D. A. is thankful to Lloyd Lynch (SRC, UWI) for information about velocity structures (LADLE Group) that are being used by the SRC to locate earthquakes in the Caribbean area, as well as to Anthony Lomax for helpful advices and for provding a script for analyzing NonLinLoc's octree grid. We would like to thank Nina Kukowski (University of Jena), François Beauducel (IPGP) and two anonymous reviewers for helpful comments for improving the manuscript. The original bulletin of the International Seismological Summary (ISS) from 1935 has been available thanks to funding provided by the US National Science Foundation through grant EAR-9725140 (Villaseñor et al., 1997) and have been scanned and collected by SGA Storia Geofisica Ambiente (Bologna) thanks to funding provided by the Istituto Nazionale di Geofisica e Vulcanologia (Rome), in the frame of EUROSEISMOS project. Maps were prepared with the GMT software package (Wessel et al., 2013).

Agnew, D. C., 2002. History of seismology. In: Lee, W. H., Jennings, P.,

Kisslinger, C., Kanamori, H. (Eds.), International Handbook of Earthquake \& Engineering Seismology. Vol. 81, Part A of International Geophysics. Academic Press, pp. 3-11.

Astiz, L., Earle, P., Shearer, P., 1996. Global stacking of broadband seismograms. Seismological Research Letters 67 (4), 8-18.

Batlló, J., Stich, D., Macià, R., 2008. Quantitative analysis of early seismograph recordings. In: Historical Seismology. Springer, pp. 385-402, DOI 10.1007/978-1-4020-8222-1_19. 
Beauducel, F., Bazin, S., Bengoubou-Valérius, M., Bouin, M.-P., Bosson, A., Anténor-Habazac, C., Clouard, V., De Chabalier, J.-B., 2011. Empirical model for rapid macroseismic intensities prediction in Guadeloupe and Martinique. Comptes Rendus Géoscience 343 (11), 717-728.

Beck, C., Reyss, J., Leclerc, F., Moreno, E., Feuillet, N., Barrier, L., Beauducel, F., Boudon, G., Clément, V., Deplus, C., et al., 2012. Identification of deep subaqueous co-seismic scarps through specific coeval sedimentation in Lesser Antilles: implication for seismic hazard. Natural Hazards \& Earth System Sciences 12 (5), 1755-1767.

Becker, J., Sandwell, D., Smith, W., Braud, J., Binder, B., Depner, J., Fabre, D., Factor, J., Ingalls, S., Kim, S., et al., 2009. Global Bathymetry and Elevation Data at 30 Arc Seconds Resolution: SRTM30_PLUS. Marine Geodesy 32 (4), $355-371$.

Bird, P., 2003. An updated digital model of plate boundaries. Geochemistry, Geophysics, Geosystems 4 (3), 1027.

Bondár, I., Engdahl, E. R., Villaseñor, A., Harris, J., Storchak, D., 2015. ISCGEM: Global Instrumental Earthquake Catalogue (1900-2009), II. Location and seismicity patterns. Physics of the Earth and Planetary Interiors 239, $2-13$.

Bondár, I., Myers, S. C., Engdahl, E. R., Bergman, E. A., 2004. Epicentre accuracy based on seismic network criteria. Geophysical Journal International $156(3), 483-496$.

Bondár, I., Storchak, D., 2011. Improved location procedures at the International Seismological Centre. Geophysical Journal International 186 (3), 12201244 .

URL http://dx.doi.org/10.1111/j.1365-246X.2011.05107.x 
Bouysse, P., Westercamp, D., Andreieff, P., 1990. The Lesser Antilles Island Arc. In: Mascle, A., Moore, J. C., Taylor, E., Underwood, M. B. (Eds.), Proc. ODP, Sci. Results. Vol. 110. Ocean Drilling Programm, College Station, TX (Ocean Drilling Programm), pp. 29-44.

Bozzoni, F., Corigliano, M., Lai, C. G., Salazar, W., Scandella, L., Zuccolo, E., Latchman, J., Lynch, L., Robertson, R., 2011. Probabilistic Seismic Hazard Assessment at the Eastern Caribbean Islands. Bulletin of the Seismological Society of America 101 (5), 2499-2521.

Chatelain, J. L., Roecker, S. W., Hatzfeld, D., Molnar, P., 1980. Microearthquake seismicity and fault plane solutions in the Hindu Kush Region and their tectonic implications. Journal of Geophysical Research: Solid Earth 85 (B3), 1365-1387.

Crotwell, H. P., Owens, T. J., Ritsema, J., 1999. The TauP Toolkit: flexible seismic travel-time and raypath utilities. Seismological Research Letters $70(2), 154-170$.

DeMets, C., Jansma, P. E., Mattioli, G. S., Dixon, T. H., Farina, F., Bilham, R., Calais, E., Mann, P., 2000. GPS geodetic constraints on Caribbean-North America Plate Motion. Geophysical Research Letters 27 (3), 437-440.

Dorel, J., 1981. Seismicity and seismic gap in the Lesser Antilles arc and earthquake hazard in Guadeloupe. Geophysical Journal International 67 (3), 679 695.

Doser, D. I., Brown, W. A., 2001. A Study of Historic Earthquakes of the Prince William Sound, Alaska, Region. Bulletin of the Seismological Society of America 91 (4), 842-857.

Engdahl, E., Villaseñor, A., 2002. 41 Global seismicity: 1900-1999. In: Lee, 
W. H., Jennings, P., Kisslinger, C., Kanamori, H. (Eds.), International Handbook of Earthquake \& Engineering Seismology. Vol. 81, Part A of International Geophysics. Academic Press, pp. 665-690.

Engdahl, E. R., Dewey, J., Fujita, K., 1982. Earthquake location in island arcs. Physics of the Earth and Planetary Interiors 30 (2-3), 145-156.

Engdahl, E. R., Van der Hilst, R. D., Buland, R., 1998. Global teleseismic earthquake relocation with improved travel times and procedures for depth determination. Bulletin of the Seismological Society of America 88 (3), $722-$ 743.

Engdahl, E. R., Villaseñor, A., DeShon, H. R., Thurber, C. H., 2007. Teleseismic Relocation and Assessment of Seismicity (1918-2005) in the Region of the $2004 \mathrm{Mw}$ 9.0 Sumatra-Andaman and 2005 Mw 8.6 Nias Island Great Earthquakes. Bulletin of the Seismological Society of America 97 (1A), S43-S61.

Feuillard, M., 1985. Macrosismicité de la Guadeloupe et de la Martinique. Institut de Physique du Globe de Paris, Paris.

Feuillet, N., Beauducel, F., Tapponnier, P., 2011. Tectonic context of moderate to large historical earthquakes in the Lesser Antilles and mechanical coupling with volcanoes. Journal of Geophysical Research: Solid Earth 116 (B10308).

Feuillet, N., Leclerc, F., Tapponnier, P., Beauducel, F., Boudon, G., Le Friant, A., Deplus, C., Lebrun, J.-F., Nercessian, A., Saurel, J.-M., et al., 2010. Active faulting induced by slip partitioning in Montserrat and link with volcanic activity: New insights from the 2009 GWADASEIS marine cruise data. Geophysical Research Letters 37 (19).

Feuillet, N., Manighetti, I., Tapponnier, P., Jacques, E., 2002. Arc parallel extension and localization of volcanic complexes in Guadeloupe, Lesser Antilles. 
Journal of Geophysical Research: Solid Earth (1978-2012) 107 (B12), ETG 3-1-ETG 3-29.

Geiger, L., 1912. Probability method for the determination of earthquake epicenters from the arrival time only (translated from Geiger's 1910 German article). Bulletin of St. Louis University 8 (1), 56-71.

Gutenberg, B., Richter, C. F., 1954. Seismicity of the Earth and Associated Phenomena, 2nd Edition. Princeton University Press, Princeton, NJ.

Havskov, J., Ottemöller, L., 2010. Routine data processing in earthquake seismology. Springer.

Husen, S., Hardebeck, J., 2010. Earthquake location accuracy. Community Online Resource for Statistical Seismicity Analysis.

International Seismological Centre, 2011a. EHB Bulletin. Int. Seis. Cent., Thatcham, United Kingdom, http://www.isc.ac.uk.

International Seismological Centre, 2011b. On-line Bulletin. Int. Seis. Cent., Thatcham, United Kingdom, http://www.isc.ac.uk.

Jeffreys, H., Bullen, K. E., 1940. Seismological tables. British Association for the Advancement of Science, London.

Kanamori, H., Lee, W. H., Ma, K.-F., 2012. The 1909 Taipei earthquakeimplication for seismic hazard in Taipei. Geophysical Journal International 191 (1), 126-146.

Kennett, B. L. N., Engdahl, E. R., 1991. Traveltimes for global earthquake location and phase identification. Geophysical Journal International 105 (2), $429-465$. 
Kennett, B. L. N., Engdahl, E. R., Buland, R., 1995. Constraints on seismic velocities in the Earth from travel times. Geophysical Journal International $122(1), 108-124$.

Kopp, H., Weinzierl, W., Becel, A., Charvis, P., Evain, M., Flueh, E., Gailler, A., Galve, A., Hirn, A., Kandilarov, A., Klaeschen, D., Laigle, M., Papenberg, C., Planert, L., Roux, E., 2011. Deep structure of the central Lesser Antilles Island Arc: Relevance for the formation of continental crust. Earth and Planetary Science Letters 304 (1-2), 121-134.

Kulhánek, O., 2002. The structure and interpretation of seismograms. In: Lee, W. H., Jennings, P., Kisslinger, C., Kanamori, H. (Eds.), International Handbook of Earthquake \& Engineering Seismology. Vol. 81, Part A of International Geophysics. Academic Press, pp. 333-348.

LADLE Study Group, 1983. A lithospheric seismic refraction profile in the western North Atlantic Ocean. Geophysical Journal International 75 (1), 23-69.

Lee, W. H., Jul. 2006. Reliable earthquake location using grid-search and simplex algorithm. presented at Second Tsunami Source Workshop of the USGS Tsunami Source Working Group (TSWG), 19 - 20 July 2006.

Lee, W. H., Baker, L. M., 2006. Abstract: Development of a direct search software package for locating poorly constrained earthquakes. Seism. Res. Lett 77, 291-292.

Lehmann, I., 1970. The Reading of Earthquake Diagrams. Geophysical Journal International 20 (4), 391-396.

Lienert, B. R., 1994. Users manual for HYPOCENTER 3.2. A Computer Program for Locating Earthquakes. Locally, Regionally and Globally. 
URL ftp://www.orfeuseu.org/pub/software/mirror/seisan/SOFTWARE/ SEISAN/Version\_6/hypocent.ps.Z

Lienert, B. R., Berg, E., Frazer, L. N., 1986. HYPOCENTER: An earthquake location method using centered, scaled, and adaptively damped least squares. Bulletin of the Seismological Society of America 76 (3), 771-783.

Lomax, A., Jun. 2005. A reanalysis of the hypocentral location and related observations for the great 1906 California earthquake. Bulletin of the Seismological Society of America 95 (3), 861-877.

Lomax, A., May 2013. NonLinLoc FAQ - Frequently Asked Questions.

URL http://alomax.free.fr/NonLinLococ

Lomax, A., Michelini, A., Curtis, A., 2009. Earthquake location, direct, globalsearch methods. In: Meyers, R. A. (Ed.), Encyclopedia of Complexity and Systems Science. Springer, pp. 2449-2473, DOI 10.1007/978-0-387-304403_150.

Lomax, A., Virieux, J., Volant, P., Berge, C., 2000. Probabilistic earthquake location in 3D and layered models. In: Thurber, C. H., Rabinowitz, N. (Eds.), Advances in Seismic Event Location. Vol. 18 of Modern Approaches in Geophysics. Springer Netherlands, pp. 101-134, DOI 10.1007/978-94-015-9536$0 \_5$.

McComb, H. E., West, C. J., 1931. List of seismological stations of the world. Second Edition. Vol. 82. The National Research Council.

Meschede, M., Frisch, W., 1998. A plate-tectonic model for the Mesozoic and Early Cenozoic history of the Caribbean plate. Tectonophysics 296 (3-4), 269291. 
Ottemöller, L., Voss, P., Havskov, J., May 2013. SEISAN EARTHQUAKE ANALYSIS SOFTWARE FOR WINDOWS, SOLARIS, LINUX and MACOSX. Version 10.0.

Petroy, D. E., Wiens, D. A., 1989. Historical seismicity and implications for diffuse plate convergence in the northeast Indian Ocean. Journal of Geophysical Research: Solid Earth 94 (B9), 12301-12319.

Powell, C. F., 1938. Royal Society Expedition to Montserrat, B.W.I. Final Report. Philosophical Transaction of the Royal Society of London. Series A, Mathematical and Physical Sciences 237 (771), 1-34.

Richter, C. F., 1958. Elementary Seismology. W. H. Freemann and Company, San Francisco.

Robson, G. R., 1964. An earthquake catalogue for the Eastern Caribbean 15301960. Bulletin of the Seismological Society of America 54 (2), 785-832.

Rothé, E., 1938. Séismologie, observations des stations françaises. In: Rothé, E. (Ed.), Annuaire de l'Institut de Physique du Globe 1935. Bureau Central Séismologique Français, Strasbourg, p. 57, in French.

Schweitzer, J., Nov. 1997. HYPOSAT-a new routine to locate seismic events. NORSAR Scientific Report 1-97/98, 94-102.

Schweitzer, J., Kennett, B. L. N., Apr. 2007. Comparison of location procedures: The Kara Sea event of 16 August 1997. Bulletin of the Seismological Society of America 97 (2), 389-400.

Sevilla, W. I., Ammon, C. J., Voight, B., De Angelis, S., 2010. Crustal structure beneath the Montserrat region of the Lesser Antilles island arc. Geochemistry, Geophysics, Geosystems 11 (Q06013). 
Stein, S., Engeln, J. F., Wiens, D. A., Speed, R. C., Fujita, K., 1983. Slow subduction of old lithosphere in the Lesser Antilles. Tectonophysics 99 (2-4), $139-148$.

Thurber, C. H., Engdahl, E. R., 2000. Advances in Global Seismic Event Location. In: Thurber, C. H., Rabinowitz, N. (Eds.), Advances in Seismic Event Location. Vol. 18 of Modern Approaches in Geophysics. Springer Netherlands, pp. 3-22, DOI 10.1007/978-94-015-9536-0_1.

Van der Hilst, R. D., Engdahl, E. R., 1992. Step-wise relocation of ISC earthquake hypocenters for linearized tomographic imaging of slab structure. Physics of the earth and planetary interiors 75 (1-3), 39-53.

Villaseñor, A., Bergman, E. A., Boyd, T. M., Engdahl, E. R., Frazier, D. W., Harden, M. M., Orth, J. L., Parkes, R. L., Shedlock, K. M., 1997. Toward a comprehensive catalog of global historical seismicity. Eos, Transactions American Geophysical Union 78 (50), 581-588.

URL http://storing.ingv.it/ISS/index.html

Wadge, G., 1986. The dykes and structural setting of the volcanic front in the Lesser Antilles island arc. Bulletin of volcanology 48 (6), 349-372.

Weber, J. C., Dixon, T. H., DeMets, C., Ambeh, W. B., Jansma, P., Mattioli, G., Saleh, J., Sella, G., Bilham, R., Pérez, O., 2001. GPS estimate of relative motion between the Caribbean and South American plates, and geologic implications for Trinidad and Venezuela. Geology 29 (1), 75-78.

Wessel, P., Smith, W. H. F., Scharroo, R., Luis, J., Wobbe, F., 2013. Generic Mapping Tools: Improved Version Released. Eos, Transactions American Geophysical Union 94 (45), 409-410. 


\section{Appendix}

Table .3: List of 196 reported phase arrival times from the ISS used in the data set D1. Nonassociated phases('*?') are identified and integrated after the first localization based on the D1 data set if a fitting association could be found.

\begin{tabular}{|c|c|c|c|c|c|c|c|}
\hline Station & Code & Arrival time & Phase & Station & Code & Arrival time & Phase \\
\hline San Juan & S.JP & $18 \mathrm{~h} 28 \min 40 \mathrm{~s}$ & $\mathrm{P}$ & Toledo & TOL & $18 \mathrm{~h} 37 \mathrm{~min} 09 \mathrm{~s}$ & $\mathrm{P}$ \\
\hline & & $\begin{array}{l}18 \mathrm{~h} 29 \mathrm{~min} 28 \mathrm{~s} \\
18 \mathrm{~h} 29 \mathrm{~min} 35 \mathrm{~s}\end{array}$ & $\stackrel{S}{*}$ & Granda & CRT & $\begin{array}{l}18 \mathrm{~h} 37 \min 14 \mathrm{~s} \\
18 \mathrm{~h} 37 \min 26 \mathrm{~s}\end{array}$ & $\begin{array}{l}\mathrm{P} \\
* ?\end{array}$ \\
\hline Port-au-Prince & PAPH & $18 \mathrm{~h} 29 \mathrm{~min} 14 \mathrm{~s}$ & $\mathrm{P}$ & & & $18 \mathrm{~h} 37 \mathrm{~min} 36 \mathrm{~s}$ & PP \\
\hline & & $18 \mathrm{~h} 31 \mathrm{~min} 56 \mathrm{~s}$ & $\mathrm{~s}$ & Berkeley & BRK & $18 \mathrm{~h} 37 \min 22 \mathrm{~s}$ & \\
\hline Balboa Heights & BHP & $18 \mathrm{~h} 32 \mathrm{~min} 00 \mathrm{~s}$ & $\mathrm{P}$ & & & $18 \mathrm{~h} 37 \min 28 \mathrm{~s}$ & $* ?$ \\
\hline Columbia & $\operatorname{CSC}$ & ${ }_{18 \mathrm{~h} 32 \mathrm{~min} 54 \mathrm{~s}}$ & $\stackrel{P}{P_{2}}$ & & & 18h50minin $4 \mathrm{~s}$ & $\begin{array}{l}\text { SSS } \\
* 2\end{array}$ \\
\hline & & $\begin{array}{l}18 \mathrm{~h} 34 \min 04 \mathrm{~s} \\
18 \mathrm{~h} 35 \min 49 \mathrm{~s}\end{array}$ & $* ?$ & & & $18 \mathrm{~h} 57 \mathrm{~min} 03 \mathrm{~s}$ & $* ?$ \\
\hline & & $18 \mathrm{~h} 37 \min 03 \mathrm{~s}$ & *? & Rathfarnham Castle & DUB & $18 \mathrm{~h} 38 \min 12 \mathrm{~s}$ & $P$ \\
\hline & & $18 \mathrm{~h} 37 \min 37 \mathrm{~s}$ & s & & & $18 \mathrm{~h} 45 \min 06 \mathrm{~s}$ & $\mathrm{~s}$ \\
\hline Charlottesville & CLT & $18 \mathrm{~h} 33 \min 08 \mathrm{~s}$ & $\mathrm{P}$ & & & $18 \mathrm{~h} 39 \min 47 \mathrm{~s}$ & *? \\
\hline & & 18h33min30s & $*$ ? & Ukiah & UKI & ${ }_{18 \mathrm{~h}}^{187 \min 24 \mathrm{~s}}$ & $\mathrm{P}$ \\
\hline Philadelphia & PHI & $18 \mathrm{~h} 33 \mathrm{~min} 12 \mathrm{~s}$ & P & & & $\begin{array}{l}18 \mathrm{~h} 4 \mathrm{~min} \min 12 \mathrm{~s} \\
18 \mathrm{~h} 5 \mathrm{~m} \min 4 \mathrm{~s}\end{array}$ & $\begin{array}{l}\mathrm{S} \\
* 2\end{array}$ \\
\hline & & $\begin{array}{l}\text { 18h33min41s } \\
\text { 18h34min21s }\end{array}$ & $\begin{array}{l}\text { PP } \\
* ?\end{array}$ & Alicante & EXAI & $\begin{array}{l}18 \mathrm{~h} 37 \mathrm{~min} 33 \mathrm{~s} \\
18 \mathrm{~h} 45 \mathrm{~min} 44 \mathrm{~s}\end{array}$ & $\mathrm{P}_{\mathrm{S}}$ \\
\hline & & $18 \mathrm{~h} 37 \min 35 \mathrm{~s}$ & s & Victoria & VIC & $18 \mathrm{~h} 45 \mathrm{~min} 40 \mathrm{~s}$ & $\mathrm{~s}$ \\
\hline & & $18 \mathrm{~h} 38 \min 16 \mathrm{~s}$ & *? & Scoresby Sund & $\mathrm{SCO}$ & $18 \mathrm{~h} 46 \mathrm{~min} 00 \mathrm{~s}$ & $\mathrm{~s}$ \\
\hline Oak Ridge & HRV & $18 \mathrm{~h} 33 \min 24 \mathrm{~s}$ & $\mathrm{P}$ & Edinburgh & EDI & $18 \mathrm{~h} 45 \min 48 \mathrm{~s}$ & s \\
\hline & & $18 \mathrm{~h} 34 \mathrm{~min} 08 \mathrm{~s}$ & PP & Oxford & OXD & $18 \mathrm{~h} 45 \min 56 \mathrm{~s}$ & s \\
\hline & & $18 \mathrm{~h} 38 \mathrm{~min} 07 \mathrm{~s}$ & s & Durham & DUR & $18 \mathrm{~h} 46 \mathrm{~min} 05 \mathrm{~s}$ & $\mathrm{~s}$ \\
\hline & & $18 \mathrm{~h} 38 \mathrm{~min} 34 \mathrm{~s}$ & *? & Kew & KEW & $18 \mathrm{~h} 46 \mathrm{~min} 00 \mathrm{~s}$ & $\mathrm{~s}$ \\
\hline & & $18 \mathrm{~h} 38 \min 43 \mathrm{~s}$ & *? & Paris & PAR & $18 \mathrm{~h} 38 \min 43 \mathrm{~s}$ & $\mathrm{P}$ \\
\hline Pennsylvania & $\mathrm{SCP}$ & $18 \mathrm{~h} 33 \mathrm{~min} 30 \mathrm{~s}$ & P & & & $18 \mathrm{~h} 47 \mathrm{~min} 00 \mathrm{~s}$ & PS \\
\hline & & $18 \mathrm{~h} 34 \min 06 \mathrm{~s}$ & ${ }^{*} \mathrm{PP}$ & Uccle & UCC & $18 \mathrm{~h} 38 \min 08 \mathrm{~s}$ & $\mathrm{P}$ \\
\hline & & 18h38min12s & $\mathrm{S}_{* 2}$ & & & ${ }_{18 \mathrm{~h}}^{186 \mathrm{~min} 30 \mathrm{~s}}$ & $\begin{array}{l}\mathrm{s} \\
\mathrm{ss}\end{array}$ \\
\hline Ithaca & ITH & $\begin{array}{l}18 \mathrm{n} 3 \mathrm{mmin} 6 \mathrm{~s} \\
18 \mathrm{~h} 3 \mathrm{~min} 42 \mathrm{~s}\end{array}$ & $\mathrm{P}$ & DeBilt & DBN & $\begin{array}{l}\text { 18h50minin } 4 \mathrm{~s} \\
18 \mathrm{~h} 46 \mathrm{~min} 42 \mathrm{~s}\end{array}$ & ss \\
\hline & & $18 \mathrm{~h} 34 \min 20 \mathrm{~s}$ & PP & & & $18 \mathrm{~h} 50 \mathrm{~min} 42 \mathrm{~s}$ & ss \\
\hline & & $18 \mathrm{~h} 34 \min 48 \mathrm{~s}$ & PPP & Strasbourg & STR & $18 \mathrm{~h} 38 \min 21 \mathrm{~s}$ & $\mathrm{P}$ \\
\hline & & $18 \mathrm{~h} 38 \mathrm{~min} 42 \mathrm{~s}$ & $\mathrm{~s}$ & & & $18 \mathrm{~h} 46 \mathrm{~min} 00 \mathrm{~s}$ & S \\
\hline Burlington & BUR & $18 \mathrm{~h} 33 \mathrm{~min} 40 \mathrm{~s}$ & $\mathrm{P}$ & Stuttgart & STU & $18 \mathrm{~h} 38 \min 27 \mathrm{~s}$ & $\mathrm{P}$ \\
\hline & & $18 \mathrm{~h} 38 \min 23 \mathrm{~s}$ & s & & & $18 \mathrm{~h} 47 \min 05 \mathrm{~s}$ & s \\
\hline & & $18 \mathrm{~h} 34 \mathrm{~min} 10 \mathrm{~s}$ & *? & & & $18 \mathrm{~h} 48 \mathrm{~min} 28 \mathrm{~s}$ & ScS \\
\hline & & $18 \mathrm{~h} 39 \mathrm{~min} 10 \mathrm{~s}$ & *? & Leipzig & LEI & $18 \mathrm{~h} 38 \min 35 \mathrm{~s}$ & $\mathrm{P}$ \\
\hline & & $18 \mathrm{~h} 39 \mathrm{~min} 45 \mathrm{~s}$ & ss & & & $18 \mathrm{~h} 38 \mathrm{~min} 38 \mathrm{~s}$ & *? \\
\hline Toronto & TNT & $18 \mathrm{~h} 33 \mathrm{~min} 45 \mathrm{~s}$ & $\mathrm{P}$ & & & $18 \mathrm{~h} 38 \min 47 \mathrm{~s}$ & *? \\
\hline & & $18 \mathrm{~h} 34 \mathrm{~min} 19 \mathrm{~s}$ & PP & & & $18 \mathrm{~h} 38 \min 57 \mathrm{~s}$ & *? \\
\hline & & $18 \mathrm{~h} 38 \min 55 \mathrm{~s}$ & $\mathrm{~S}$ & & & $18 \mathrm{~h} 39 \mathrm{~min} 23 \mathrm{~s}$ & *? \\
\hline & & $18 \mathrm{~h} 39 \mathrm{~min} 57 \mathrm{~s}$ & sS & & & $18 \mathrm{~h} 39 \mathrm{~min} 36 \mathrm{~s}$ & *? \\
\hline Ottawa & ОТТ & 18h34mino0s & $\begin{array}{l}\mathrm{P} \\
\mathrm{S}\end{array}$ & & & $18 \mathrm{~h} 39 \min 48 \mathrm{~s}$ & *? \\
\hline & & 18h39min00s & $\mathrm{S}$ & & & $18 \mathrm{~h} 40 \mathrm{~min} 04 \mathrm{~s}$ & *? \\
\hline Huancayo & HUA & $18 \mathrm{~h} 34 \mathrm{~min} 01 \mathrm{~s}$ & P & & & $18 \mathrm{~h} 40 \min 17 \mathrm{~s}$ & *? \\
\hline & & 18h35min41s & $\begin{array}{l}\text { PPP } \\
* *\end{array}$ & & & $\begin{array}{l}\text { 18h40minin } 4 \mathrm{~s} \\
\text { 18h47minin } 2 \mathrm{~s}\end{array}$ & s? \\
\hline & & 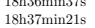 & *? & & & $18 \mathrm{~h} 48 \mathrm{~min} 30 \mathrm{~s}$ & $\mathrm{SeS}$ \\
\hline & & $18 \mathrm{~h} 39 \mathrm{~min} 07 \mathrm{~s}$ & $\mathrm{~s}$ & Copenhagen & $\mathrm{COP}$ & $18 \mathrm{~h} 38 \mathrm{~min} 41 \mathrm{~s}$ & $\mathrm{P}$ \\
\hline Ann Arbor & AAM & $18 \mathrm{~h} 35 \mathrm{~min} 36 \mathrm{~s}$ & $\mathrm{P}$ & & & $18 \mathrm{~h} 47 \min 38 \mathrm{~s}$ & \\
\hline & & $18 \mathrm{~h} 39 \mathrm{~min} 12 \mathrm{~s}$ & S & & & $18 \mathrm{~h} 48 \mathrm{~min} 34 \mathrm{~s}$ & $\mathrm{ScS}$ \\
\hline Saint Louis & SLM & $18 \mathrm{~h} 34 \mathrm{~min} 13 \mathrm{~s}$ & $\mathrm{P}$ & & & $18 \mathrm{~h} 52 \mathrm{~min} 06 \mathrm{~s}$ & ss \\
\hline & & $18 \mathrm{~h} 35 \mathrm{~min} 10 \mathrm{~s}$ & PP & & & $18 \mathrm{~h} 55 \mathrm{~min} 00 \mathrm{~s}$ & SSS \\
\hline & & $18 \mathrm{~h} 35 \min 16 \mathrm{~s}$ & $?$ & Trieste & TRS & $18 \mathrm{~h} 38 \min 43 \mathrm{~s}$ & $\mathrm{P}$ \\
\hline & & $18 \mathrm{~h} 39 \min 28 \mathrm{~s}$ & s & & & $18 \mathrm{~h} 47 \min 46 \mathrm{~s}$ & s \\
\hline & & $18 \mathrm{~h} 41 \mathrm{~min} 04 \mathrm{~s}$ & Ss & & & $18 \mathrm{~h} 48 \min 27 \mathrm{~s}$ & PS \\
\hline Little Rock & LRA & $18 \mathrm{~h} 34 \min 06 \mathrm{~s}$ & $\mathrm{P}$ & & & $18 \mathrm{~h} 49 \mathrm{~min} 09 \mathrm{~s}$ & *? \\
\hline & & $18 \mathrm{~h} 35 \min 05 \mathrm{~s}$ & $?$ & Prague & PRA & $18 \mathrm{~h} 47 \min 48 \mathrm{~s}$ & s \\
\hline & & $18 \mathrm{~h} 35 \min 17 \mathrm{~s}$ & PP & Uppsala & UPP & $18 \mathrm{~h} 38 \min 29 \mathrm{~s}$ & $\mathrm{P}$ \\
\hline & & 18h39min $22 \mathrm{~s}$ & $?$ & & & $18 \mathrm{~h} 48 \min 06 \mathrm{~s}$ & S \\
\hline & & 18h39min21s & S & Sofia & SOF & $\begin{array}{l}18 \mathrm{~h} 39 \mathrm{~min} 32 \mathrm{~s} \\
\end{array}$ & $\begin{array}{l}\mathrm{P} \\
\mathrm{S}\end{array}$ \\
\hline Florissant & FLO & $\begin{array}{l}18 \mathrm{~h} 4 \mathrm{mmin} 0 \mathrm{~s} \\
18 \mathrm{~h} 4 \mathrm{~min} 14 \mathrm{~s}\end{array}$ & P & Pulkovo & PUL & $\begin{array}{l}\text { 18h49minin } 0 \mathrm{~s} \\
\text { 18h39minss }\end{array}$ & P \\
\hline & & $18 \mathrm{~h} 35 \min 23 \mathrm{~s}$ & ? & & & $18 \mathrm{~h} 49 \mathrm{~min} 20 \mathrm{~s}$ & s \\
\hline & & $18 \mathrm{~h} 35 \min 49 \mathrm{~s}$ & ? & Moscow & MOS & $18 \mathrm{~h} 40 \mathrm{~min} 01 \mathrm{~s}$ & P \\
\hline & & $18 \mathrm{~h} 39 \mathrm{~min} 29 \mathrm{~s}$ & $\mathrm{~s}$ & & & $18 \mathrm{~h} 50 \mathrm{~min} 15 \mathrm{~s}$ & $\mathrm{~s}$ \\
\hline & & $18 \mathrm{~h} 41 \mathrm{~min} 09 \mathrm{~s}$ & ? & & & $18 \mathrm{~h} 51 \mathrm{~min} 07 \mathrm{~s}$ & PS \\
\hline & & $18 \mathrm{~h} 41 \mathrm{~min} 23 \mathrm{~s}$ & ? & & & $18 \mathrm{~h} 51 \mathrm{~min} 22 \mathrm{~s}$ & *? \\
\hline & & $18 \mathrm{~h} 42 \min 03 \mathrm{~s}$ & ? & & & $18 \mathrm{~h} 55 \mathrm{~min} 29 \mathrm{~s}$ & ss \\
\hline Chicago & CHK & $18 \mathrm{~h} 39 \mathrm{~min} 20 \mathrm{~s}$ & s & Simferopol & SIM & $18 \mathrm{~h} 40 \mathrm{~min} 09 \mathrm{~s}$ & $\mathrm{P}$ \\
\hline & & $18 \mathrm{~h} 40 \mathrm{~min} 36 \mathrm{~s}$ & *? & Yalta & YAL & $18 \mathrm{~h} 40 \mathrm{~min} 11 \mathrm{~s}$ & $\mathrm{P}$ \\
\hline La Paz & LPZ & 18h34min21s & $\mathrm{P}$ & Helwan & HLW & $18 \mathrm{~h} 40 \min 22 \mathrm{~s}$ & $\begin{array}{l}\mathrm{P} \\
\mathrm{S}\end{array}$ \\
\hline & & $18 \mathrm{~h} 35 \min 42 \mathrm{~s}$ & $\begin{array}{l}\mathrm{PP} \\
\mathrm{S}\end{array}$ & & & 18h50min $42 \mathrm{~s}$ & $\begin{array}{l}\mathrm{S} \\
\mathrm{PP}\end{array}$ \\
\hline & & $18 \mathrm{~h} 39 \mathrm{~min} 49 \mathrm{~s}$ & $\begin{array}{l}\mathrm{S} \\
\mathrm{SS}\end{array}$ & $K=$ & & $18 \mathrm{~h} 44 \min 53 \mathrm{~s}$ & PP \\
\hline & & $18 \mathrm{~h} 41 \mathrm{~min} 54 \mathrm{~s}$ & SS & Ksara & KSA & $18 \mathrm{~h} 40 \mathrm{~min} 31 \mathrm{~s}$ & P \\
\hline Madison & MDS & $18 \mathrm{~h} 34 \min 37 \mathrm{~s}$ & $\begin{array}{l}\mathrm{P} \\
\mathrm{S}\end{array}$ & & & $18 \mathrm{~h} 51 \mathrm{~min} 12 \mathrm{~s}$ & S \\
\hline Sucre & SUC & $\begin{array}{l}18 \mathrm{~h} 40 \mathrm{~min} n 0 \mathrm{~s} \\
18 \mathrm{~h} 3 \mathrm{~min} 42 \mathrm{~s}\end{array}$ & $\begin{array}{l}\mathrm{S} \\
\mathrm{P}\end{array}$ & Grozny & GRO & $\begin{array}{l}\text { 18h52minin } 0 \mathrm{~s} \\
18 \mathrm{~h} 43 \min 37 \mathrm{~s}\end{array}$ & $\begin{array}{l}\text { PS } \\
\text { P }\end{array}$ \\
\hline Tucson & TUO & $18 \mathrm{~h} 36 \mathrm{~min} 04 \mathrm{~s}$ & $\mathrm{P}$ & Tiblissi & TIF & $18 \mathrm{~h} 40 \mathrm{~min} 52 \mathrm{~s}$ & $\mathrm{P}$ \\
\hline & & $18 \mathrm{~h} 42 \min 46 \mathrm{~s}$ & s & & & $18 \mathrm{~h} 51 \mathrm{~min} 21 \mathrm{~s}$ & SKS \\
\hline & & $18 \mathrm{~h} 42 \mathrm{~min} 13 \mathrm{~s}$ & *? & & & $18 \mathrm{~h} 51 \mathrm{~min} 48 \mathrm{~s}$ & $\mathrm{~s}$ \\
\hline & & $18 \mathrm{~h} 42 \min 56 \mathrm{~s}$ & PS & Cape Town & $\mathrm{CGH}$ & $18 \mathrm{~h} 51 \mathrm{~min} 23 \mathrm{~s}$ & $\mathrm{~s}$ \\
\hline & & $18 \mathrm{~h} 46 \mathrm{~min} 06 \mathrm{~s}$ & SS & & & $18 \mathrm{~h} 59 \mathrm{~min} 22 \mathrm{~s}$ & *? \\
\hline & & $18 \mathrm{~h} 46 \mathrm{~min} 43 \mathrm{~s}$ & *? & Sverdlovsk & SVE & $18 \mathrm{~h} 40 \min 58 \mathrm{~s}$ & $\mathrm{P}$ \\
\hline Bozeman & BZM & $18 \mathrm{~h} 43 \min 39 \mathrm{~s}$ & S & & & $18 \mathrm{~h} 51 \mathrm{~min} 48 \mathrm{~s}$ & \\
\hline La Plata & LPA & $18 \mathrm{~h} 45 \min 24 \mathrm{~s}$ & s & & & $18 \mathrm{~h} 51 \mathrm{~min} 22 \mathrm{~s}$ & SKS \\
\hline & & 18h48mino0s & SS & & & ${ }_{18 \mathrm{~h}}^{183 \mathrm{~min} 0} 0 \mathrm{~s} \mathrm{~s}$ & PS \\
\hline La Jolla & LJC & $18 \mathrm{~h} 36 \mathrm{~min} 49 \mathrm{~s}$ & $\mathrm{P}$ & & & $18 \mathrm{~h} 58 \min 18 \mathrm{~s}$ & SS \\
\hline Riverside & RVR & $18 \mathrm{~h} 36 \mathrm{~min} 49 \mathrm{~s}$ & $\mathrm{P}$ & Baku & BAK & $18 \mathrm{~h} 51 \mathrm{~min} 46 \mathrm{~s}$ & s \\
\hline Mount Wilson & MWC & $18 \mathrm{~h} 36 \mathrm{~min} 56 \mathrm{~s}$ & $\mathrm{P}$ & & & $19 \mathrm{~h} 06 \mathrm{~min} 10 \mathrm{~s}$ & *? \\
\hline Pasadena & PAS & $\begin{array}{l}18 \mathrm{~h} 36 \min 55 \mathrm{~s} \\
18 \mathrm{~h} 48 \min 17 \mathrm{~s}\end{array}$ & $\begin{array}{l}\mathrm{P} \\
\mathrm{S}\end{array}$ & Tashkent & TAS & $\begin{array}{l}18 \mathrm{~h} 45 \min 11 \mathrm{~s} \\
18 \mathrm{~h} 46 \min 17 \mathrm{~s}\end{array}$ & $\begin{array}{l}\mathrm{P} \\
\mathrm{PP}\end{array}$ \\
\hline San Fernando & SFS & $18 \mathrm{~h} 44 \mathrm{~min} 28 \mathrm{~s}$ & s & & & $18 \mathrm{~h} 52 \mathrm{~min} 35 \mathrm{~s}$ & $\mathrm{~S}$ \\
\hline Haiwee & HAI & $18 \mathrm{~h} 36 \mathrm{~min} 56 \mathrm{~s}$ & $\mathrm{P}$ & & & $18 \mathrm{~h} 55 \mathrm{~min} 30 \mathrm{~s}$ & PS \\
\hline Tinemaha & TIN & $18 \mathrm{~h} 36 \mathrm{~min} 57 \mathrm{~s}$ & $\mathrm{P}$ & & & $19 \mathrm{~h} 06 \mathrm{~min} 30 \mathrm{~s}$ & sss \\
\hline Santa Barbara & $\mathrm{SBC}$ & $18 \mathrm{~h} 37 \min 05 \mathrm{~s}$ & $\mathrm{P}$ & Kodaikanal & KOD & $18 \mathrm{~h} 50 \mathrm{~min} 25 \mathrm{~s}$ & PKS \\
\hline Malaga & MAL & $18 \mathrm{~h} 37 \min 22 \mathrm{~s}$ & P & Manila & MAN & $18 \mathrm{~h} 47 \mathrm{~min} 36 \mathrm{~s}$ & $\mathrm{P}$ \\
\hline & & 18h37min25s & *? & & & & \\
\hline & & $18 \mathrm{~h} 37 \min 33 \mathrm{~s}$ & *? & & & & \\
\hline & & $18 \mathrm{~h} 37 \min 37 \mathrm{~s}$ & *? & & & & \\
\hline
\end{tabular}


Table .4: Combined listing of the NonLinLoc output based on the model ak135 for the data sets D2 and D3

\begin{tabular}{|c|c|c|c|c|c|c|c|c|c|c|c|}
\hline & Code & & & & & & & & $\begin{array}{l}\text { D3 } \\
\text { Weight }\end{array}$ & & \\
\hline & S.IP & 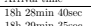 & 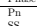 & 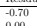 & 1.12 & (3.73 & 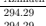 & - & 1.111 & 3.73 & 291.36 \\
\hline Balboa Heights & BHP & 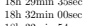 & P & $\begin{array}{l}0.00 \\
2.46\end{array}$ & 0.99 & $\begin{array}{l}3.73 \\
18.38 \\
\end{array}$ & $\begin{array}{l}246.58 \\
246.58 \\
2\end{array}$ & $\begin{array}{l}-2.31 \\
2.31 \\
-126\end{array}$ & $\begin{array}{l}1.11 \\
0.99 \\
1\end{array}$ & $\begin{array}{l}3.73 \\
18.38 \\
\end{array}$ & 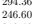 \\
\hline $\begin{array}{l}\text { Colmimial } \\
\text { Charlotessille }\end{array}$ & CLT & 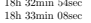 & & $\begin{array}{l}-1.184 \\
-1.90 \\
-190\end{array}$ & $\begin{array}{l}0.93 \\
0.92\end{array}$ & $\begin{array}{l}2.3 .35 \\
25.40 \\
20\end{array}$ & $\begin{array}{l}399.40 \\
32961\end{array}$ & $\begin{array}{l}-2.204 \\
-2.10 \\
-10\end{array}$ & $\begin{array}{l}0.91 \\
0.90\end{array}$ & $\begin{array}{l}23.86 \\
25.40\end{array}$ & $\begin{array}{l}319.40 \\
32.61\end{array}$ \\
\hline Philaddelphia & PHI & $\begin{array}{l}18 \mathrm{~h} 37 \mathrm{~min} 36 \mathrm{sec} \\
18 \mathrm{~s} 33 \mathrm{~min} 1 \mathrm{sec}\end{array}$ & $\begin{array}{c}S \\
\mathrm{p} \\
\mathrm{p}\end{array}$ & $\begin{array}{l}1.34 \\
0.52 \\
0.5\end{array}$ & $\begin{array}{l}0.92 \\
0.97\end{array}$ & $\begin{array}{l}25.40 \\
25.57\end{array}$ & $\begin{array}{l}329.61 \\
333.12\end{array}$ & 1.22 & 0.92 & $\begin{array}{l}25.40 \\
25.58 \\
25.58\end{array}$ & $\begin{array}{l}329.61 \\
337312 \\
32712\end{array}$ \\
\hline Oat Pidat & & 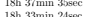 & & -2.2 .22 & 0.86 & 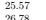 & 337.12 & -2.54 & 0.84 & 25.58 & \\
\hline Jakr fugage & 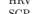 & 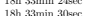 & & 1.00 & & 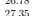 & & 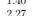 & & 年 & 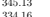 \\
\hline & BUR & 18h 33minin 4bsee & & -2.66 & 0.86 & 29.04 & 34.22 & -2.86 & 0.84 & & 34.22 \\
\hline avasa & OTT & 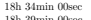 & & 0.00 & 0.11 & 30.60 & 311.66 & 0.00 & 0.11 & 30.60 & 31..66 \\
\hline Hnancayo & HUA & $18 \mathrm{~h} 34 \mathrm{~min} 01 \mathrm{sec}$ & P & 0.00 & 0.16 & 31.58 & 201.42 & 0.00 & 0.17 & 31.58 & 201.43 \\
\hline Little Rock & LRA & $18 \mathrm{~h} 35 \mathrm{~min} 17 \mathrm{sec}$ & & 1.64 & . & $\begin{array}{l}5.158 \\
32.07\end{array}$ & $\begin{array}{l}2014.42 \\
330.69\end{array}$ & 1.38 & 酸 & $\begin{array}{l}3.158 \\
32.08\end{array}$ & $\begin{array}{l}201.43 \\
309969 \\
3096\end{array}$ \\
\hline Syint Lovis & s5e & 18h 39min $21 \mathrm{sec}$ & & & 0.91 & 32.07 & 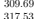 & 1.26 & 0.90 & $\begin{array}{l}32.08 \\
32565 \\
3\end{array}$ & 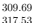 \\
\hline & & $\begin{array}{l}18 \mathrm{~h} 39 \mathrm{~min} 28 \mathrm{sec} \\
18 \mathrm{sec}\end{array}$ & $\mathrm{s}$ & 0.90 & 0.92 & 32.55 & 317.53 & $\begin{array}{l}-.079 \\
0.79\end{array}$ & 0.91 & 32.56 & 317.53 \\
\hline & FLO & $\begin{array}{l}18 \mathrm{1} 3 \mathrm{3} 3 \mathrm{~min} 14 \mathrm{sec} \\
1 \mathrm{sh} 35 \min 32 \mathrm{sec}\end{array}$ & & $\begin{array}{l}-1.17 \\
-0.78\end{array}$ & $\begin{array}{l}0.93 \\
0.94 \\
-10\end{array}$ & $\begin{array}{l}32.73 \\
32.73 \\
3.5\end{array}$ & $\begin{array}{l}377.68 \\
317.68\end{array}$ & $\begin{array}{l}-1.36 \\
-1.04\end{array}$ & $\begin{array}{l}0.92 \\
0.93 \\
-10\end{array}$ & $\begin{array}{l}32.74 \\
3.274 \\
3\end{array}$ & $\begin{array}{l}317.68 \\
31768 \\
3.768\end{array}$ \\
\hline & & 18h 39min 29sec & & -0.899 & & 32.73 & 317.68 & -1.01 & 0.90 & & \\
\hline $\mathrm{Aa}_{\mathrm{Paz}}$ & LPZ & 18h 39min 49sec & & 1.68 & 1.33 & 33.85 & 189.66 & 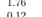 & 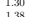 & $\begin{array}{l}3.3 .35 \\
3.35\end{array}$ & 189.67 \\
\hline Madison & MDS & $18 \mathrm{~h} 40 \mathrm{~min} 00 \mathrm{sec}$ & $\mathrm{s}$ & -1.25 & 0.90 & 34.76 & 321.59 & -1.37 & 0.89 & 34.76 & 324.59 \\
\hline Tucson & TUO & $18 \mathrm{~h} 36 \mathrm{~min} 04 \mathrm{sec}$ & & 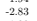 & 0.87 & $\begin{array}{l}36.14 \\
46.14\end{array}$ & $\begin{array}{l}1791.88 \\
298.80\end{array}$ & $\begin{array}{l}-2.201 \\
-3.00 \\
\end{array}$ & 0.84 & $\begin{array}{l}36.03 \\
46.14\end{array}$ & 2098.81 1919 \\
\hline & BZM & 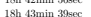 & & $\begin{array}{l}-1.38 \\
1.32\end{array}$ & 0.93 & $\begin{array}{l}89.64 \\
4944\end{array}$ & $\begin{array}{l}2 \\
2385.80 \\
316,62\end{array}$ & 1.23 & 0.92 & 49.44 & 316.42 \\
\hline Jolla & & $18 \mathrm{~h} 36 \mathrm{~min} 49 \mathrm{sec}$ & & . 0.37 & $\begin{array}{l}1.01 \\
099 \\
099\end{array}$ & $\begin{array}{l}51.58 \\
5177\end{array}$ & 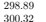 & $\begin{array}{l}0.21 \\
-0.21\end{array}$ & $\begin{array}{l}1.01 \\
0.98 \\
0.9\end{array}$ & 51.59 & 298.89 \\
\hline Nount Hamilton & MWC & ${ }_{18 \mathrm{sh}} 36 \mathrm{sin}$ in $56 \mathrm{sec}$ & & 1.61 & - & 52.36 & 300.55 & 1.45 & & & 300.55 \\
\hline Pasadena & PAS & $18 \mathrm{~h} 36 \mathrm{~min} 55 \mathrm{5sec}$ & & -0.03 & 1.02 & 52.45 & 300.44 & -0.20 -0.20 & 1.01 & 52.45 & 300.45 \\
\hline & & 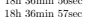 & & $\begin{array}{l}0.93 \\
-0.49\end{array}$ & $\begin{array}{l}1.00 \\
101\end{array}$ & 52.78 & $\begin{array}{l}3012.96 \\
30.108\end{array}$ & 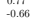 & 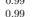 & 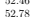 & 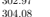 \\
\hline San Fernando & SFS & 18h $44 \min 28 \mathrm{sec}$ & & -2.01 & 0.97 & 53.23 & 56.72 & -2.02 & 0.96 & 53.23 & .72 \\
\hline $\begin{array}{l}\text { Santa Barbara } \\
\text { Granada }\end{array}$ & $\begin{array}{l}\mathrm{SBC} \\
\mathrm{CRT}\end{array}$ & $\begin{array}{l}18 \mathrm{sin} 37 \mathrm{~min} \text { 1055ec } \\
1 \mathrm{~h} 37 \mathrm{~min} 14 \mathrm{sec}\end{array}$ & P & $\begin{array}{l}0.43 \\
-2.44 \\
-\end{array}$ & $\begin{array}{l}1.02 \\
0.96\end{array}$ & $\begin{array}{l}5.3 .34 \\
55.38\end{array}$ & $\begin{array}{l}360.69 \\
56.07\end{array}$ & 然.2.57 & $\begin{array}{l}1.01 \\
0.95\end{array}$ & $\begin{array}{l}\frac{5.37 .75}{55.38} \\
58\end{array}$ & $\begin{array}{l}300.70 \\
56.07\end{array}$ \\
\hline Berkley & BRK & $\begin{array}{l}18 \mathrm{sin} 37 \min 265 \mathrm{sec} \\
18 \mathrm{~h} 37 \mathrm{~min} \\
222 \mathrm{sec}\end{array}$ & P & $\begin{array}{l}0.60 \\
0.76\end{array}$ & 1.01 & $\begin{array}{l}56.58 \\
56.05\end{array}$ & $\begin{array}{l}50.67 \\
30.69 \\
309\end{array}$ & 0.60 & 1.01 & 56.05 & 304.70 \\
\hline toria & VIC & 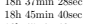 & 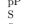 & $\begin{array}{l}-2.222 \\
2.38 \\
-2.3\end{array}$ & $\begin{array}{l}0.94 \\
0.90\end{array}$ & $\begin{array}{l}5.6 .35 \\
58.30\end{array}$ & $\begin{array}{l}3141.69 \\
317.13\end{array}$ & 2.30 & 0.89 & 58.31 & 317.13 \\
\hline 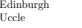 & $\begin{array}{l}\text { EDI } \\
\text { UCC }\end{array}$ & 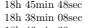 & $P$ & $\begin{array}{l}-0.099 \\
2.08\end{array}$ & $\begin{array}{l}0.98 \\
0.95 \\
0.95\end{array}$ & $\begin{array}{l}5.9 .513 \\
62.51\end{array}$ & $\begin{array}{l}3.19 \\
40.97 \\
4097\end{array}$ & $\begin{array}{l}-.033 \\
1.93 \\
1.94\end{array}$ & $\begin{array}{l}0.99 \\
0.97\end{array}$ & $\begin{array}{l}59.13 \\
62.51 \\
61\end{array}$ & $\begin{array}{l}34.18 \\
40.97 \\
407\end{array}$ \\
\hline DeBilt & DBN & 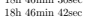 & & $\begin{array}{l}-1.218 \\
2.21\end{array}$ & 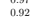 & $\begin{array}{l}0.2 .17 \\
6.3 .17\end{array}$ & $\begin{array}{l}4.997 \\
33.58\end{array}$ & $\begin{array}{l}-15010 \\
2109\end{array}$ & 0 & 63.18 & 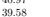 \\
\hline asbourg & STR & $18 \mathrm{~h} 38 \mathrm{smin} 21 \mathrm{sec}$ & & 1.85 & 0.98 & 64.511 & 43.65 & 1.71 & 0.99 & 64.51 & 43.65 \\
\hline 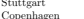 & $\begin{array}{l}\text { STO } \\
\text { COP }\end{array}$ & 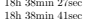 & & $\begin{array}{l}1.66 \\
1.16\end{array}$ & 0.99 & $\begin{array}{l}6.564 \\
6674\end{array}$ & $\begin{array}{l}4.3999 \\
3605\end{array}$ & 1.53 & $\begin{array}{l}1.01 \\
1.02 \\
-102\end{array}$ & 6. & 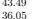 \\
\hline & & & & 2.40 & & 67.74 & 36.05 & & 0.92 & & \\
\hline & TRS & 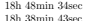 & SKS & $\begin{array}{l}-1.84 \\
-1.84 \\
\end{array}$ & 0.95 & $\begin{array}{l}67.74 \\
685\end{array}$ & $\begin{array}{l}36.05 \\
1689\end{array}$ & $\begin{array}{l}-1.83 \\
-1.83 \\
-2.22\end{array}$ & $\begin{array}{l}0.96 \\
098 \\
0.9\end{array}$ & & 36. \\
\hline & & $\begin{array}{l}18 \mathrm{~h} 47 \min 465 \mathrm{sec} \\
\end{array}$ & & 0.39 & 1.03 & 68.57 & 46.88 & 0.38 & 1.04 & 68.58 & 46.88 \\
\hline $\begin{array}{l}\text { Pulkowo } \\
\text { Plate }\end{array}$ & $\begin{array}{l}\text { PRA } \\
\text { PUL }\end{array}$ & $\begin{array}{l}18 \mathrm{~h} 47 \mathrm{~min} 44 \mathrm{sec} \\
18 \mathrm{~h} 39 \mathrm{~min} 35 \mathrm{sec}\end{array}$ & & $\begin{array}{l}-1.21 \\
0.21\end{array}$ & 1.04 & $\begin{array}{l}0.88 \\
76.95 \\
765\end{array}$ & $\begin{array}{l}12.111 \\
31.09\end{array}$ & $\begin{array}{ll}-1.28 \\
0.08\end{array}$ & $\begin{array}{l}1.000 \\
1.05 \\
\end{array}$ & 95 & $\begin{array}{l}4.211 \\
31.09 \\
3\end{array}$ \\
\hline & & & & & & & & & & & \\
\hline Mloscow & Mos & 18h $40 \mathrm{~min} 01 \mathrm{sec}$ & & 0.13 & $1.07 \mathrm{~T}$ & $\begin{array}{l}8.173 \\
s_{173}\end{array}$ & 3.4.06 & 0.000 & 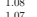 & $\begin{array}{l}81.73 \\
{ }_{81737}\end{array}$ & 34.06 \\
\hline & SMM & 18h 40 min $09 \mathrm{sec}$ & P & 2.59 & 0.97 & 82.79 & 45.13 & 2.47 & 0.99 & 82.79 & 45.13 \\
\hline & & $\begin{array}{l}18 \mathrm{~h} 40 \mathrm{~min} \\
18 \mathrm{sec}\end{array}$ & shos & 1.08 & & 87.48 & $\begin{array}{l}0.5 .37 \\
55.35\end{array}$ & 0.96 & 1.15 & & \\
\hline Cape Town & CGH & 18h $15 \mathrm{smin} 233 \mathrm{sec}$ & SKS & -0.49 & 2.96 & 92.26 & 124.90 & -0.41 & 2.97 & 92.25 & \\
\hline thkent & TAS & $18 \mathrm{~h} 52 \mathrm{~min} 335 \mathrm{sec}$ & s & -0.63 & 1.29 & 106.79 & 35.75 & -0.61 & 1.33 & 106.80 & (3.7. \\
\hline Kodaikanal & & 18h 50min 25sec & & & & & & & & & \\
\hline
\end{tabular}




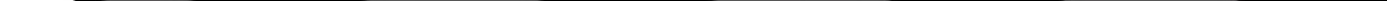

